ORNL-3528

UC-4 - Chemistry

TID-4500 (24th ed.)

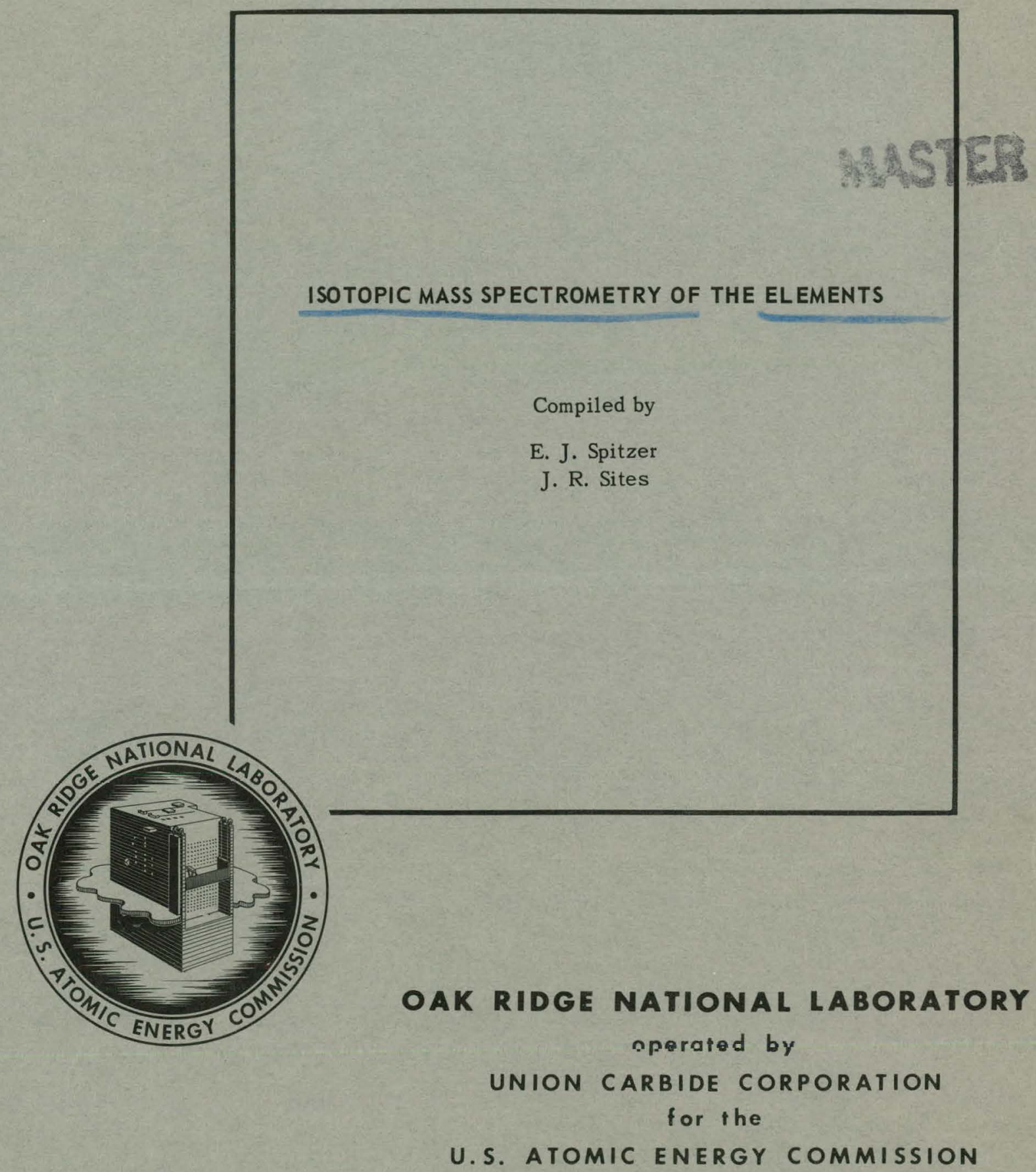




\section{DISCLAIMER}

This report was prepared as an account of work sponsored by an agency of the United States Government. Neither the United States Government nor any agency Thereof, nor any of their employees, makes any warranty, express or implied, or assumes any legal liability or responsibility for the accuracy, completeness, or usefulness of any information, apparatus, product, or process disclosed, or represents that its use would not infringe privately owned rights. Reference herein to any specific commercial product, process, or service by trade name, trademark, manufacturer, or otherwise does not necessarily constitute or imply its endorsement, recommendation, or favoring by the United States Government or any agency thereof. The views and opinions of authors expressed herein do not necessarily state or reflect those of the United States Government or any agency thereof. 


\section{DISCLAIMER}

Portions of this document may be illegible in electronic image products. Images are produced from the best available original document. 


\section{Printed in USA. Price: $\$ 2.00$ Available from the Office of Technical Services \\ U. S. Department of Commerce \\ Washington 25, D. C.}

\section{LEGAL NOTICE}

This report was prepared as an account of Government sponsored work. Neither the United States, nor the Commission, nor any person acting on behalf of the Commission:

A. Makes any warranty or representation, expressed or implied, with respect to the accuracy, completeness, or usefulness of the information contained in this report, or that the use of any information, apparatus, method, or process disclosed in this report may not infringe privately owned rights; or

B. Assumes any liabilities with respect to the use of, or for damages resulting from the use of any information, apparatus, method, or process disclosed in this report.

As used in the above, "person acting on behalf of the Commission" includes any employee or contractor of the Commission, or employee of such contractor, to the extent that such employee or contractor of the Commission, or employee of such contractor prepares, disseminates, or provides access to, any information pursuant to his employment or contract with the Commission, or his employment with such contractor. 
ORNL-3528

Contract No. W-7405-eng-26

ANALYTICAL CHEMISTRY DIVISION

ISOTOPIC MASS SPECTROMETRY OF THE ELEMENTS

Compiled by

E. J. Spitzer

J. R. Sites

Date Issued

DEC 979928

OAK RIDGE NATIONAL LABUKATORY

Oak Ridge, Tennessee

operated by

UNION CARBIDE CORPORATION

for the

U. S. ATOMIC ENERGY COMMISSION 
THIS PAGE

\section{WAS INTENTIONALLY LEFT BLANK}


THIS PAGE

WAS INTENTIONALLY

LEFT BLANK 


\section{CONTENTS}

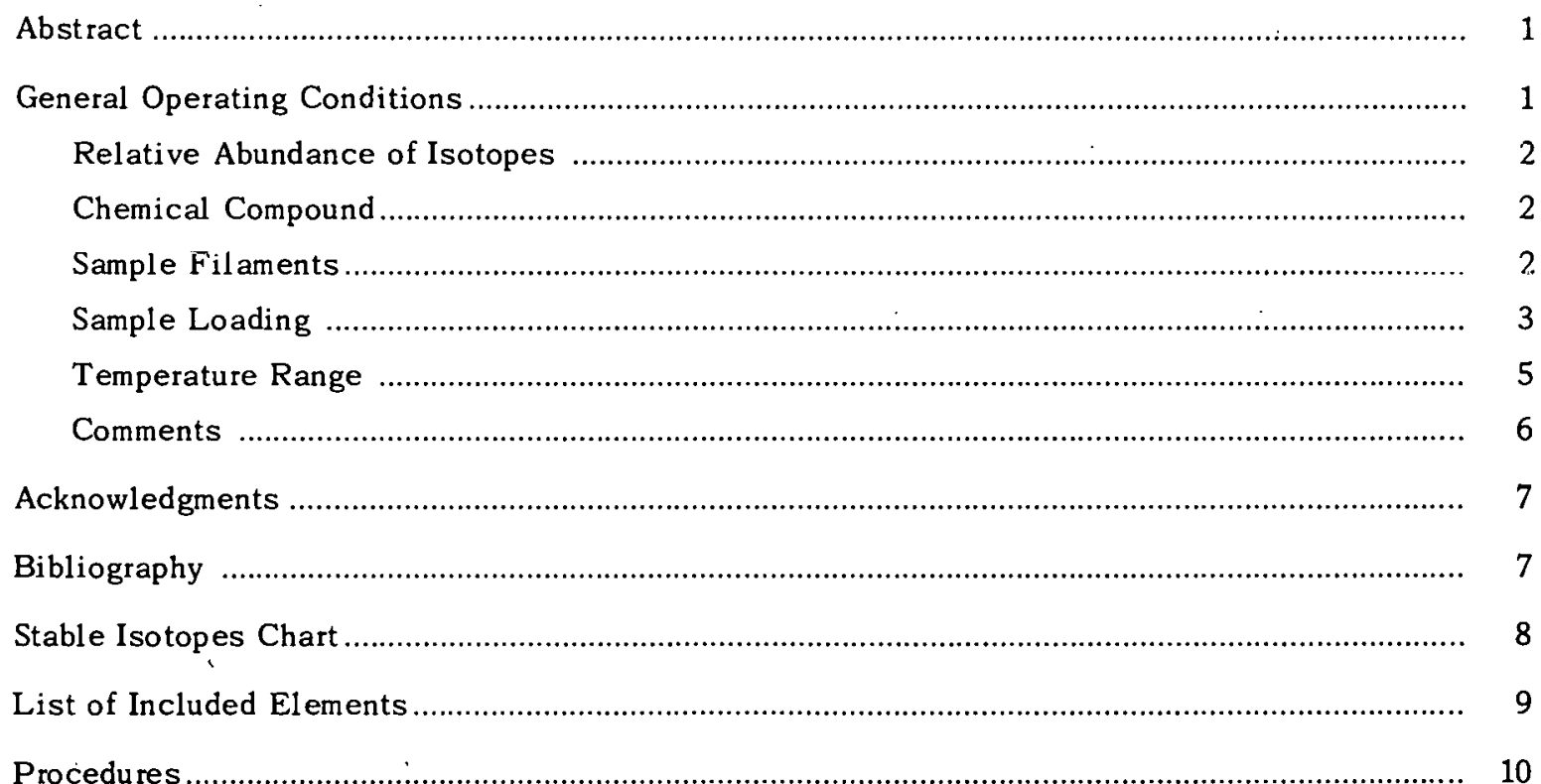




\title{
ISOTOPIC MASS SPECTROMETRY OF THE ELEMENTS
}

\author{
Compiled by \\ E. J. Spitzer J.R. Sites
}

\begin{abstract}
The Analytical Mass Spectrometry Section at Oak Ridge National Laboratory has, for many years, been determining relative isotopic abundances from solid samples. Thus, useful analytical mass spectrometer experience with every pertinent element has been obtained. These include the 55 polyis otopic elements as well as products of irradiation and fission.

The techniques used have been summarized in this report. A separate page for each element lists preferred compound, loading of sample, manner of obtaining a stable ion beam, and solutions of special problems.

These procedures are used daily in the mass spectrometry laboratory, and changes and improvements are frequently being made. They represent a collection of the experimental work of many people. Sometimes several samples a day, each of a different element, must be analyzed on a given mass spectrometer, and it is inefficient not to have a quirk-recall aid, such as these procedures. This report certainly does not contain the ultimate nor exhaustive listing of methods but only those currently in use.
\end{abstract}

\section{GENERAL OPERATING CONDITIONS}

Many mass spectrometry laboratories are now determining relative isotopic abundances from solid samples, and other laboratories will be interested in similar analysis in the future. For many years, the Analytical Mass Spectrometry Section of the Oak Ridge National Laboratory has been analyzing isotopes for the Stable Isotopes Separations Group. All 55 of the polyisotopic elements have been separated. The resulting enriched isotopes have been analyzed and made available for loan or sale. Isotopic changes in the products of irradiation, as well as in fission products, are also determined. Thus, useful analytical mass spectrometric experience with every pertinent element has been obtained. It is the purpose of this report to indicate the equipment, outline the general methods used, and itemize the variations in technique required for each element.

All data reported herein were obtained by means of a $60^{\circ}$ deflection, sector-type noncommercial metal mass spectrometer. Conventional ion-focusing and accelerating slit systems were used, the ionization chambers being so constructed as to accept expendable bases of the samplesupporting filaments. The filaments are resistance-heated using current-regulated power supplies. The magnet current control permits one to repetitively scan up and down at various rates over a mass range continuously adjustable from a fraction of a mass unit to the full mass range. The magnetically analyzed ion eurrent3, collccted on a vane behind an adjustable slit, go 
through the $10^{10}$-ohm input resistor of a vibrating reed electrometer, and the mass spectra are displayed on a strip chart recorder.

\section{Relative Abundance of Isotopes}

The relative abundances of isotopes listed for each element were taken from the $1959 \mathrm{Nu}$ clear Data Tables.*

\section{Chemical Compound}

For the separated stable isotopes, it was hoped that the preferred inventory compound of the element could also be used for the mass analysis. For most elements this is true; however, for some, specially prepared compounds are much better. In a few cases, any simple compound of the element can be used.

Certain physical and chemical properties are desirable. For example, a suitable compound should be chemically stable at room temperature. Also, it is desirable for it to be soluble in water or dilute acid. Sometimes special care is required because the evaporated coating pops off the filament as a result of loss of water of hydration. Stable vaporization may be achieved by using unusual compounds that give thermal decomposition products of high vapor pressure; for example, $\mathrm{BaSiF}_{6}$ for silicon and $\mathrm{Ag}_{6} \mathrm{TeO}_{6}$ for tellurium.

\section{Sample Filaments}

Several metal filaments are used; however, the most commonly used filament is a $0.001 \times$ $0.030 \times 0.500$ in. dimpled tantalum ribbon, as shown in Fig. 1. The base used to support the sample filament has a standard octal configuration, with two opposite pins eliminated. The 0.060 -in.-diam pins can carry heavy currents, and a single filament is spot-welded across the center pins. The four side pins can be used either for alignment with the sides of the ionization chamber or to support a second filament. These bases cost less than $50 \$$ each. A long dimple is formed in most of the filaments, greatly aiding in the retention of the sample material in the central portion. Simple hand-drawn pipets used for samples in solution are discarded after use. A micromanipulator is not needed in any of these loading techniques. The same sample filament configuration is used for either thermal or electron-bombardment ionization. The distance between the ionization chamber exit slit and the filament is $1 / 4$ in., which allows enough space for the electron beam to pass when using bombardment ionization.

Filaments of tungsten, iridium, rhenium, and platinum are also used. Prebaking the filament is necessary for the analysis of potassium, calcium, strontium, and barium. This can be done in

${ }^{*}$ K. Way (ed.), 1959 Nuclear Data Tables, Supt. of Documents, U.S. Government Printing Office, Washington 25, D.C. 


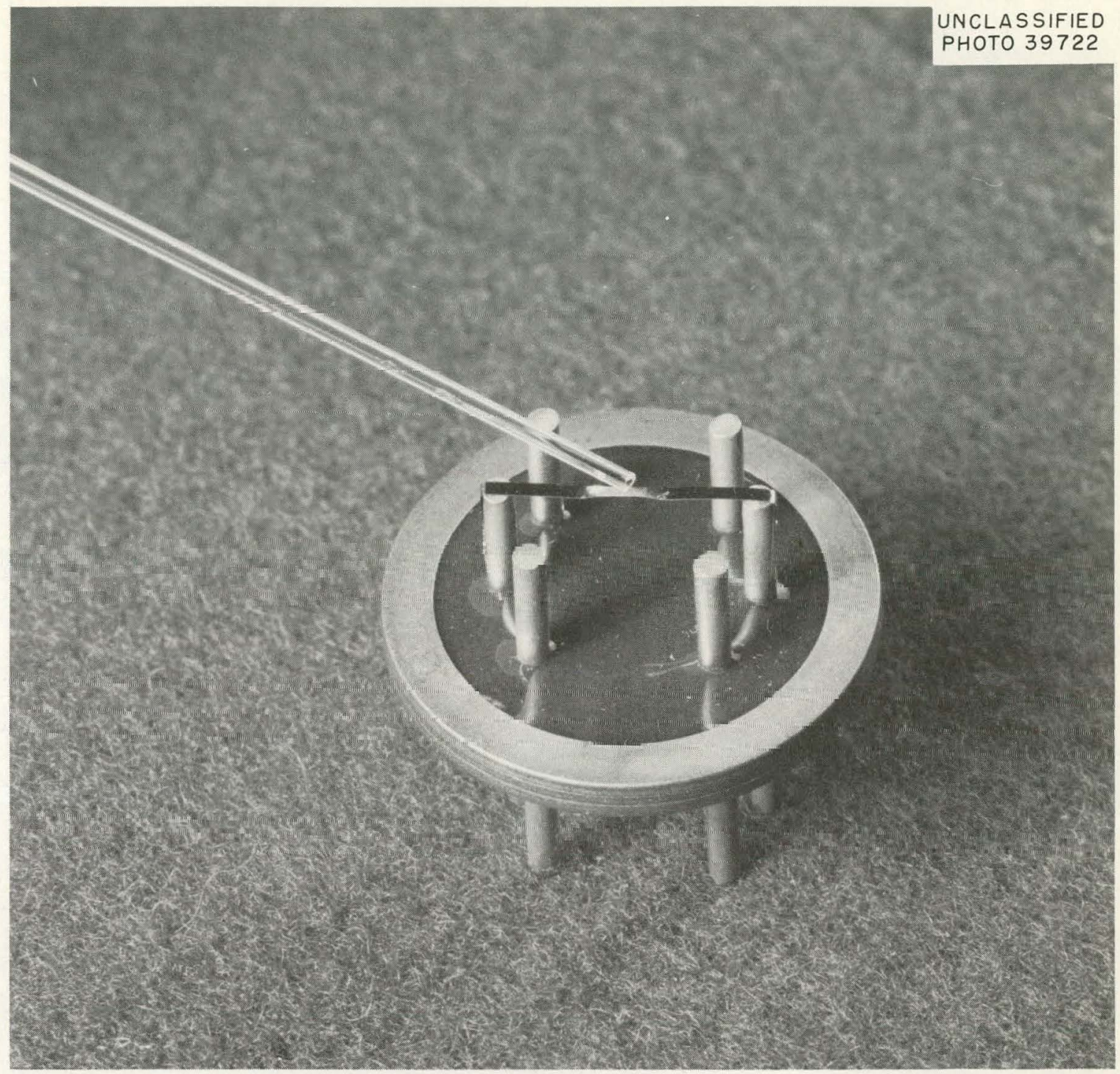

Fig. 1. Sample Filament.

the mass spectrometer to observe the amount of background ion intensity at operating temperatures, or they can be baked in an auxiliary vacuum chamber using a heating cycle that has proved to be satisfactory.

\section{Sample Loading}

The sample loading facilities are shown in Fig. 2. The filament base is supported on a small bell-jar flange under the microscope, and a filament can be baked under vacuum to elimirlate surface contamination, to fuse a sample, or to reduce an oxide. Accessories are pipets, 


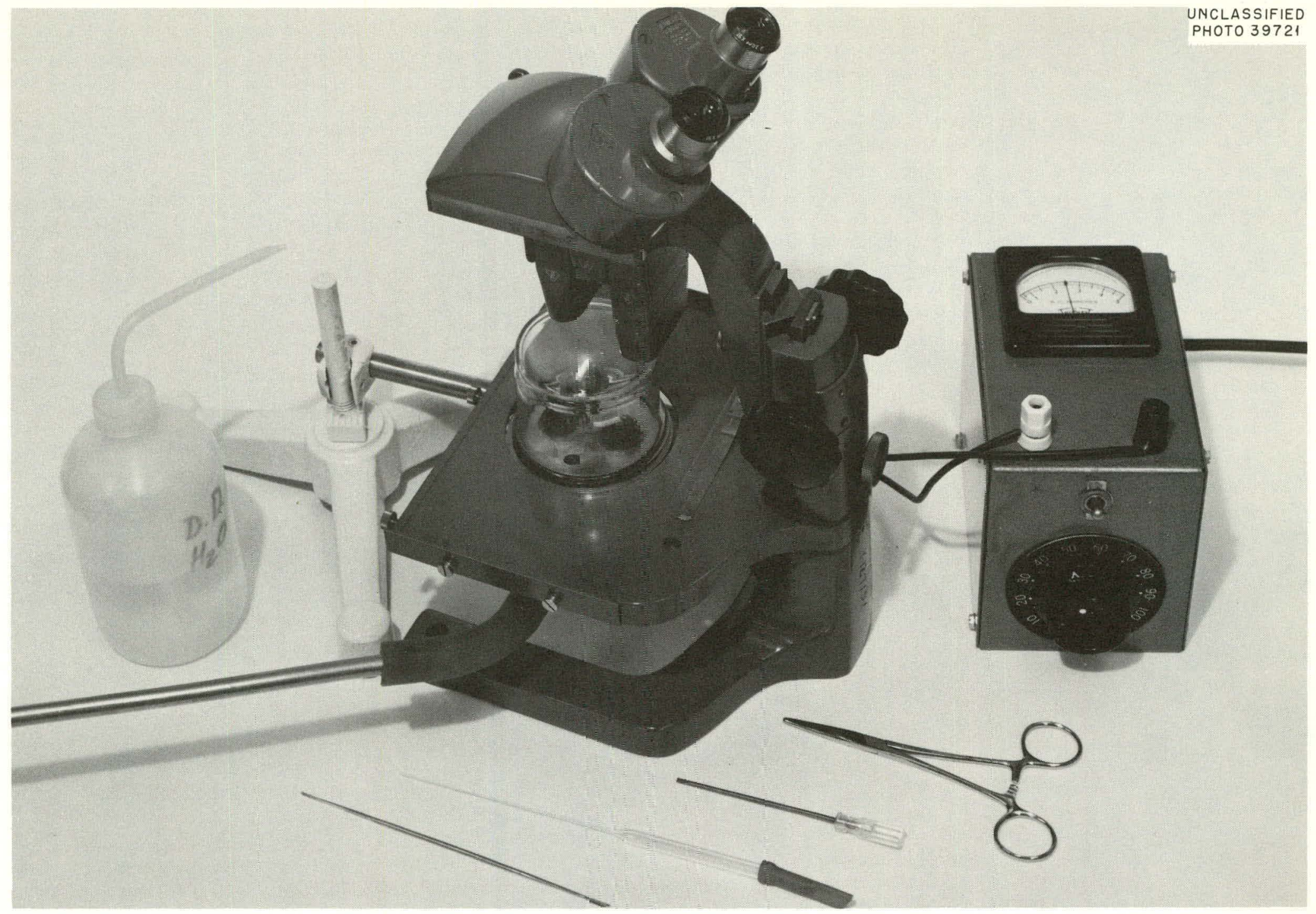

Fig. 2. Sample Loading Facilities. 
hemostats, small spatula, and tweezers. Triply distilled water from a polyethylene bottle gives no extra background ions.

The samples placed on the filament vary from a few milligrams to a few nanograms, depending on availability, radioactivity, and volatility which would contribute to memory in the spectrometer source.

Most compounds load very easily on the filament when deposited from a dilute nitrate solution - for example, uranium. A few finely divided powders will slurry with a dropiet of water or dilute nitric acid, as the rare-earth oxides. Some fuse on the filament, as does $\mathrm{NaCl}$. The usual procedure for loading a platinum-group metal is to fuse it to the proper filament material at a high temperature under vacuum. Boron compounds are added to sodium hydroxide which has been fused on the filament, and further heating forms sodium tetraborate. Fluffy materials and hard materials are crimped into a folded canoe-type filament. Treating $\mathrm{CaO}$ and $\mathrm{CaCO}_{3}$ with $\mathrm{HI}$ gives much more steady ion beams of $\mathrm{Ca}$ ions. Initial heating of a tantalum filament in air to give a faint blue oxide layer frequently makes the ion beam much more stable. Watching the many loading procedures through the microscope enables one to see phase changes, completion of reactions, or as is sometimes the case only crust from an impure sample.

\section{Temperature Range}

The temperature range listed includes the first appearance of the desired ion peaks to the intensity sufficient for obtaining data (approximately $10^{-14}$ to $10^{-10} \mathrm{amp}$ ). The filament size has been selected so that the current needed to reach the maximum temperature is less than 5 amp, and the filament temperature is controlled by a current regulating supply. In some cases, a $0.002 \times 0.060$ in. tantalum filament acts as a heat sink. This helps to maintain a slow rate of sample volatilization when the ambient temperature in the source region is too high due to the electron-bombardment filament. In daily practice, the chart shown in Fig. 3 is more convenient to use than an optical pyrometer to determine desired filament temperature.

A bit of experience and finesse is needed in the sequence of raising the filament temperature for some compounds, or the sample may be lost. Also, many analyses are made at a temperature near the melting point of the filament material - for example, some of the platinum-group elements. In some cases, a few sets of data are taken at each increase in ion intensity because the ion beam may deteriorate after the next temperature increase. Frequently, temperature below that for data taking is maintained for a phase change, for background reduction, or for smoother vaporization conditions. Fractional distillation in the spectrometer is sometimes utilized. For example, a small amount of rubidium in a strontium sample will bake out at a lower temperature than that at which the strontium data are taken. Stable ion intensities for some elements, such as the rare-earth elements, can be obtained by 'setting the filament supply to the proper current. 


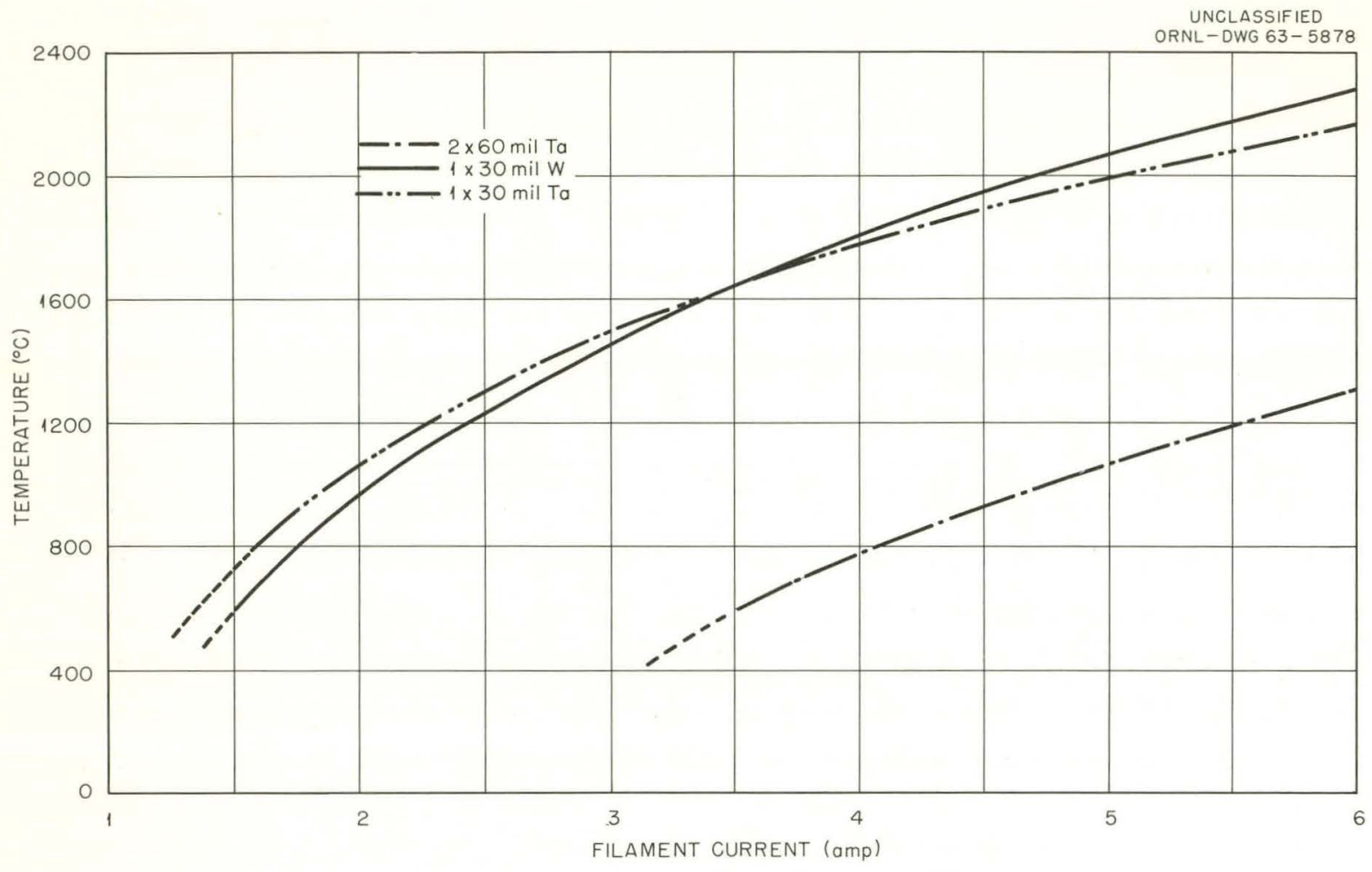

Fig. 3. Filament Temperature Conversion Chart.

\section{Comments}

Circumstances continually arise that keep mass spectrometry from becoming too routine.

Interfering peaks are often present. For electron-bombardment ion beams, the hydrocarbon background from pump oil or fingerprints may be very persistent. Water in the sample or a small air leak may hinder by keeping the pressure too high.

Corrections for hydrocarbon background often can be made by subtracting a typical background pattern for the mass region, us ing a nonisorbaric background peak as a base. Corrections for oxygen isotopes are made when necessary, as in analysis of rare-earth oxide ions. All filament materials give sodium, potassium, rubidium, strontium, cesium, and barium ions. Rhenium contains molybdenum, and iridium contains rhodium. Thus, prebaking or proper selection of filament material is required.

The submitted sample may be "clean" to the chemist or the optical spectroscopist and still give bothersome ions of sodium, potassium, etc. In cleaning a uranium solution by extraction, salting with $\left(\mathrm{NH}_{4}\right)_{2} \mathrm{CO}_{3}$ instead of $\mathrm{CaCO}_{3}$ permits steady uranium ion beams of high intensity. Residues of resins and other organics can prevent smooth vaporization and ionization of many compounds. 
Isobars can cause errors in peak heights, as among rare-earth elements and for rubidium and strontium. Differences in vapor pressures are enough that isobar interference appears in the form of an ion beam of changing intensity with respect to interference-free ions, and corrections can be made.

Memory from one run to the next can often be controlled without cleaning the source parts between each analysis by using removable shields, or by analyzing several samples of nearly the same isotopic enrichment. Sometimes, analyzing a "high temperature" sample or two before changing to a different isotope of a "low temperature" set of samples is sufficient.

\section{ACKNOWLEDGMENTS}

Many of the compounds used were originally suggested and prepared by W. C. Davis of the Isotopes Division. Most of the procedures have been developed by M. M. Honaker, C. E. Prather, and the compilers, or by other mass spectrometry groups in Oak Ridge. J. R. Walton performed much of the original development. Some of the procedures were taken from the open literature and were adapted to the available equipment.

\section{BIBLIOGRAPHY}

Inghram, M. G., and R. J. Hayden, Mass Spectroscopy, Nuclear Science Series Report No. 4, National Academy of Sciences, Washington 25, D.C., 1954.

Turnbull, A. H., Surface Ionisation Techniques in Mass Spectrometry, AERE-R-4295 (1963).

Waldron, J. D. (ed.), Advances in Mass Spectrometry, Pergamon Press, New York, 1959.

Walton, J. R., Solid Sample Mass Spectrometer Analyses of Enriched Stable Isotopes, ORNL2315 (1957).

Way, K. (ed.), 1959 Nuclear Duta Tables, Superintendent of Documents, U.S. Government Printing Office, Washington 25, D.C. 
UNCLASSIFIED
ORNL-LR-DWG 77306
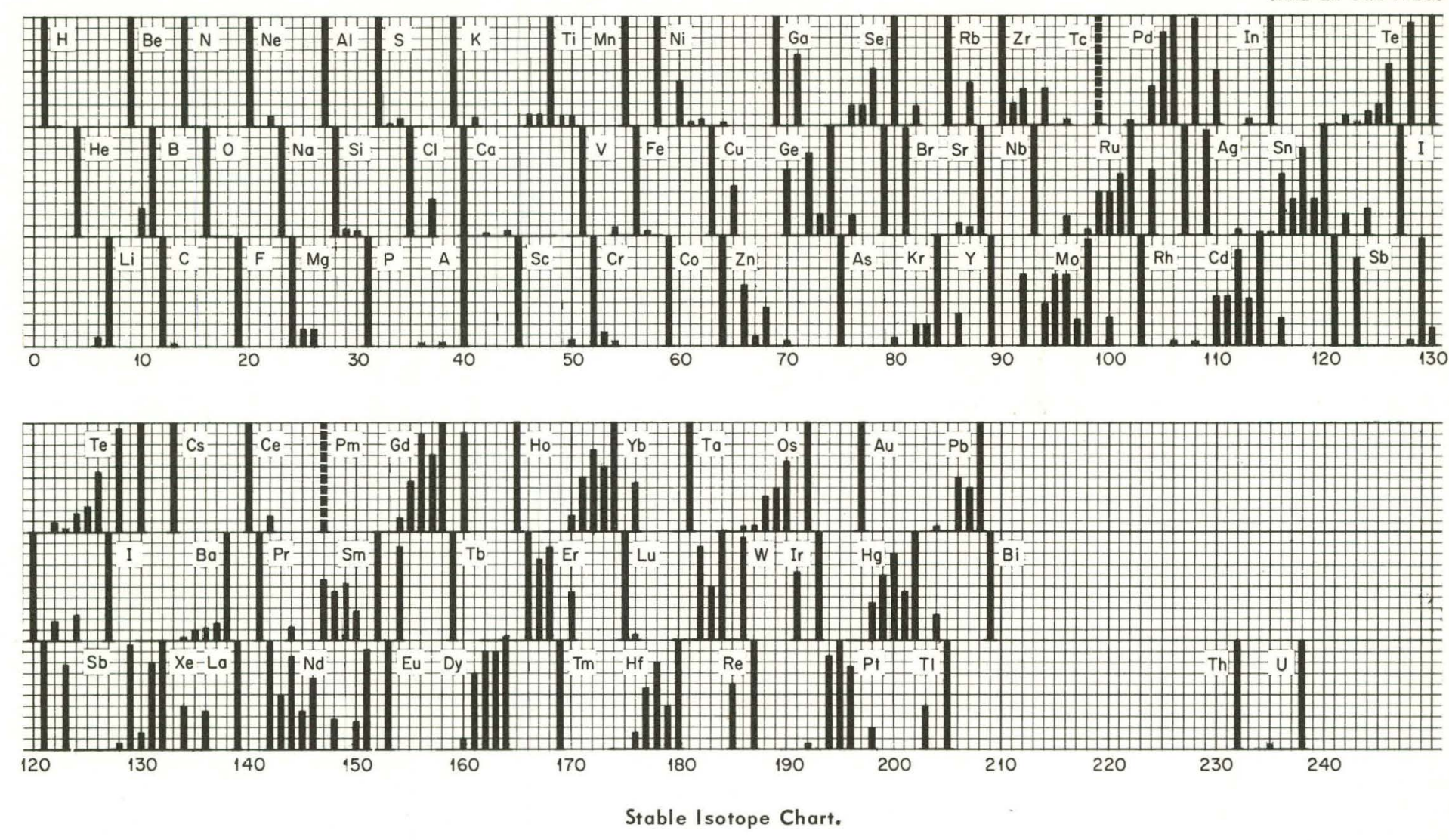


\section{LIST OF INCLUDED ELEMENTS}

$\begin{array}{ll}\text { Aluminum } & \text { Neptunium } \\ \text { Antimony } & \text { Nickel } \\ \text { Barium } & \text { Osmium } \\ \text { Boron } & \text { Palladium } \\ \text { Bromine } & \text { Platinum } \\ \text { Cadmium } & \text { Potassium } \\ \text { Caesium } & \text { Praseodymium } \\ \text { Calcium } & \text { Rhenium } \\ \text { Cerium } & \text { Rubidium } \\ \text { Chlorine } & \text { Ruthenium } \\ \text { Chromium } & \text { Samarium } \\ \text { Copper } & \text { Selenium } \\ \text { Dysprosium } & \text { Silicon } \\ \text { Erbium } & \text { Silver } \\ \text { Europium } & \text { Sodium } \\ \text { Gadolinium } & \text { Strontium } \\ \text { Gallium } & \text { Sulfur } \\ \text { Germanium } & \text { Tantalum } \\ \text { Hafnium } & \text { Technetium } \\ \text { Holmium } & \text { Tellurium } \\ \text { Indium } & \text { Terbium } \\ \text { Iodine } & \text { Thallium } \\ \text { Iridium } & \text { Thorium } \\ \text { Iron } & \text { Thulium } \\ \text { Lanthanum } & \text { Tin } \\ \text { Lead } & \text { Titanium } \\ \text { Lithium } & \text { Tungsten } \\ \text { Lutctium } & \text { Uranium } \\ \text { Magnesium } & \text { Vanadium } \\ \text { Mercury } & \text { Ytterbium } \\ \text { Molybdenum } & \text { Zinc } \\ \text { Neodymium } & \\ \text { Mirconium }\end{array}$




\begin{tabular}{|c|c|c|c|}
\hline \multirow{2}{*}{\multicolumn{2}{|c|}{ Preferred Conditions }} & \multicolumn{2}{|c|}{$\begin{array}{c}\text { Relative Abundance } \\
\text { of Isotopes }\end{array}$} \\
\hline & & Isotope & Atom \% \\
\hline Compound & $\mathrm{Al}_{2} \mathrm{O}_{3}$ & 27 & 100 \\
\hline Sample filament & Tungsten & & \\
\hline Filament size & $1 \times 30 \mathrm{mils}$ & & \\
\hline Ionization & Thermal & & \\
\hline Temperature range & $1300-1600^{\circ} \mathrm{C}$ & & \\
\hline Ion measured & $\mathrm{Al}^{+}$ & & \\
\hline
\end{tabular}

\section{Sample Loading}

Place finely divided aluminum oxide on the filament and slurry with distilled water. Dry the sample with a gentle heat.

\section{Comments}

The temperature at which $\mathrm{Al}^{+}$first appears is unpredictable and may vary over a wide range.

Interference from previous aluminum samples has not been observed. 
Antimony

\begin{tabular}{ll||cc}
\hline \multicolumn{1}{c||}{} & \multicolumn{2}{c}{$\begin{array}{c}\text { Relative Abundance } \\
\text { of Isotopes }\end{array}$} \\
\cline { 3 - 3 } & Preferred Conditions & Isotope $\%$ \\
Compound & $\mathrm{Sb}$ & 121 & 57.25 \\
Filample filament & Tantalum & 123 & 42.75 \\
Ionization & $1 \times 30 \mathrm{mils}$ & & \\
Temperature range & Electron bombardment & & \\
Ion measured & $<400-750^{\circ} \mathrm{C}$ & \\
\hline
\end{tabular}

\section{Sample Loading}

Place antimony on the filament; increase the temperature slowly until sample melts.

\section{Comments}

The optimum temperature must be approached slowly after $\mathrm{SbO}^{+}$first appears.

The ratio of $\mathrm{Sb}^{+}$to $\mathrm{SbO}^{+}$is approximately $1: 10$.

Interference from previous antimony samples is a problem.

Correction for $\mathrm{O}^{18}$ may be necessary. 


\section{Barium}

\begin{tabular}{|c|c|c|c|}
\hline \multirow{2}{*}{\multicolumn{2}{|c|}{ Preferred Conditions }} & \multicolumn{2}{|c|}{$\begin{array}{l}\text { Relative Abundance } \\
\text { of Issotopes }\end{array}$} \\
\hline & & \multirow{2}{*}{$\begin{array}{c}\text { Is otope } \\
130\end{array}$} & \multirow{2}{*}{$\begin{array}{r}\text { Atom \% } \\
0.101\end{array}$} \\
\hline Compound & $\mathrm{Ba}\left(\mathrm{NO}_{3}\right)_{2}$ & & \\
\hline Sample filament & Tantalum & 132 & 0.097 \\
\hline Filament size & $1 \times 30 \mathrm{mils}$ & 134 & 2.42 \\
\hline Ionization & Thermal & 135 & 6.59 \\
\hline Temperature range & $1300-1650^{\circ} \mathrm{C}$ & 136 & 7.81 \\
\hline \multirow{2}{*}{ Ion measured } & \multirow[t]{2}{*}{$\mathrm{Ba}^{+}$} & 137 & 11.32 \\
\hline & & 138 & 71.66 \\
\hline
\end{tabular}

\section{Sample Looding}

Place barium nitrate on the filament; increase the temperature slowly until the sample melts. If the temperature is increased too rapidly the sample will "pop" off the filament. Melting $\mathrm{Ba}\left(\mathrm{NO}_{3}\right)_{2}$ will require $\sim 3$ amp when heated in air.

\section{Coments}

Most tantalum filaments contain residual barium. The major part of the impurities can be removed by prebaking the filament at $6.0 \mathrm{amp}$ for $2 \mathrm{~min}$ at a pressure of $<5 \times 10^{-5}$ torr.

When the sample is submitted as $\mathrm{BaCO}_{3}$, load it on the filament and then add a drop of concentrated nitric acid and complete the preparation as described for the nitrate.

The temperature at which $\mathrm{Ba}^{+}$first appears is unpredictable and may vary over a wide range.

The temperature must be increased slowly because excessive heat generally produces an erratic beam.

Interference from previous barium samples is a problem.

The intensity ratio of $\mathrm{Ba}^{+}$to $\mathrm{BaO}^{+}$varies widely and is not constant. 
Boron

\begin{tabular}{|c|c|c|c|}
\hline \multirow{2}{*}{\multicolumn{2}{|c|}{ Preferred Conditions }} & \multicolumn{2}{|c|}{$\begin{array}{c}\text { Relative Abundance } \\
\text { of Isotopes }\end{array}$} \\
\hline & - & \multirow{2}{*}{$\begin{array}{c}\text { Isotope } \\
10\end{array}$} & \multirow{2}{*}{$\begin{array}{c}\overline{\text { Atom } \%} \\
19.61\end{array}$} \\
\hline Compound & $\mathrm{Na}_{2} \mathrm{~B}_{4} \mathrm{O}_{7}$ & & \\
\hline Sample filament & Tantalum & 11 & 80.39 \\
\hline Filament size & $1 \times 30 \mathrm{mils}$ & & \\
\hline Ionization & Thermal & & \\
\hline Temperature range & $750-1000^{\circ} \mathrm{C}$ & & \\
\hline Iori meas ured & $\mathrm{Na}_{2} \mathrm{BO}_{2}{ }^{+}$ & & \\
\hline
\end{tabular}

\section{Sample Loading}

Place sodium tetraborate on the filament; increase the temperature slowly until the sample melts.

\section{Comments}

Two micrograms of boron, as $\mathrm{Na}_{2} \mathrm{~B}_{4} \mathrm{O}_{7}$, have produced an ion current of $5 \times 10^{-12}$ amp with very slow decay ( $\sim 5 \%$ in $10 \mathrm{~min}$ ).

$\mathrm{B}^{10}$ and $\mathrm{B}^{11}$, as $\mathrm{Na}_{2} \mathrm{BO}_{2}{ }^{+}$, have masses at 88 and 89 .

Boron metal or compounds, such as $\mathrm{B}_{2} \mathrm{O}_{3}, \mathrm{H}_{2} \mathrm{BO}_{3}$, and $\mathrm{B}_{4} \mathrm{C}$, are converted to sodium tetraborate by fusing them in a small pellet of $\mathrm{NaOH}$. This is done on the filament, and the temperature is then increased to a red heat $\left(\sim 750^{\circ} \mathrm{C}\right)$.

Interference from previous boron samples has not been observed.

$\mathrm{Sr}^{88}$ can give interference. Correction for $\mathrm{O}^{17}$ may be necessary. 


\section{Bromine}

\begin{tabular}{|c|c|c|c|}
\hline \multirow{2}{*}{\multicolumn{2}{|c|}{ Preferred Conditions }} & \multicolumn{2}{|c|}{$\begin{array}{c}\text { Relative Abundance } \\
\text { of Isotopes }\end{array}$} \\
\hline & & \multirow{2}{*}{$\begin{array}{c}\text { Isotope } \\
79\end{array}$} & \multirow{2}{*}{$\begin{array}{l}\text { Atom \% } \\
50.537\end{array}$} \\
\hline Compound & $\mathrm{NaBr}$ & & \\
\hline Sample filament & Tàntalum & 81 & 49.463 \\
\hline Filament size & $1 \times 30 \mathrm{mils}$ & & \\
\hline Ionization & Electron bombardment & & \\
\hline Temperature range & $400-1000^{\circ} \mathrm{C}$ & & \\
\hline Ion measured & $\mathrm{NaBr}^{+}$ & & \\
\hline
\end{tabular}

\section{Sample Looding}

Place sodium bromide on the filament; increase the temperature slowly until the sample melts.

\section{Comments}

The $\mathrm{NaBr}^{+}$intensity will decrease soon after it first appears. Additional increases of temperature will produce a stable and higher ion current. 
Cadmium

\begin{tabular}{ll||cc}
\hline \multicolumn{1}{l||}{} & \multicolumn{1}{c||}{ Preferred Conditions } & \multicolumn{2}{c}{$\begin{array}{c}\text { Relative Abundance } \\
\text { of Isotopes }\end{array}$} \\
\cline { 3 - 4 } & & Isotope & Atom \% \\
\hline Compound & CdO & 106 & 1.215 \\
Sample filament & Tantalum & 108 & 0.875 \\
Filament size & $1 \times 30$ mils & 110 & 12.39 \\
Ionization & Electron bombardment & 111 & 12.75 \\
Temperature range & $800-1100^{\circ} \mathrm{C}$ & 112 & 24.07 \\
Ion measured & $\mathrm{Cd}^{+}$ & 113 & 12.26 \\
& & 114 & 28.86 \\
& & 116 & 7.58 \\
\hline
\end{tabular}

\section{Somple Loading}

Place finely divided cadmium oxide on the filament and slurry with distilled water. Dry the sample with a gentle heat.

\section{Comments}

The $\mathrm{Cd}^{+}$intensity will decrease soon after it first appears. Additional increase of temperature will produce a stable and higher ion current.

Interference from previous cadmium samples is a serious problem.

Palmer* reported that $\mathrm{CdSO}_{4}$ dissolved in borax gave thermal ions $\left(\mathrm{Cd}^{+}\right)$at $900{ }^{\circ} \mathrm{C}$ from a tungsten filament.

*G. H. Palmer, in Advances in Mass Spectrometry, ed. by J. D. Waldron, Pergamon Fress, New York, 1959. 


\section{Coesium}

\begin{tabular}{|c|c|c|c|}
\hline \multicolumn{2}{|c|}{ Preferred Conditions } & \multicolumn{2}{|c|}{$\begin{array}{c}\text { Relative Abundance } \\
\text { of Isotopes }\end{array}$} \\
\hline & & \multirow{2}{*}{$\frac{\text { Isotope }}{133}$} & \multirow{2}{*}{$\begin{array}{c}\text { Atom \% } \\
100\end{array}$} \\
\hline Compound & $\mathrm{Cs}_{2} \mathrm{SnCl}_{6}$ & & \\
\hline Sample filament & Tantalum & ' & \\
\hline Filament size & $1 \times 30 \mathrm{mils}$ & & \\
\hline Ionization & Thermal & & \\
\hline Temperature range & $600-800^{\circ} \mathrm{C}$ & & \\
\hline Ion measured & $\mathrm{Cs}^{+}$ & & \\
\hline
\end{tabular}

\section{Sample Loading}

Place caesium chlorostannate solution on the filament and dry with a gentle heat.

\section{Comments}

Some tantalum filaments contain residual caesium. The major part of the impurities can be removed by prebaking the filament at $6.0 \mathrm{amp}$ for $1.5 \mathrm{~min}$ at a pressure of $<5 \times 10^{-5}$ torr .

The temperature must be increased slowly because excessive heat generally produces an erratic beam.

Interference from previous caesium samples is a problem.

Interference from $\mathrm{Ba}^{+}$is possible, but $\mathrm{Cs}^{+}$usually appears at a lower temperature than $\mathrm{Ba}^{+}$.

Many other Cs salts readily ionize and can be used for mass analysis. 


\section{Calcium}

\begin{tabular}{ll||cc}
\hline \multicolumn{2}{c||}{ Preferred Conditions } & \multicolumn{2}{c}{$\begin{array}{c}\text { Relative Abundance } \\
\text { of Isotopes }\end{array}$} \\
\cline { 3 - 4 } & & Isotope & Atom \% \\
\hline Compound & $\mathrm{CaCO}_{3}$ & 40 & 96.97 \\
Sample filament & Tantalum & 42 & 0.64 \\
Filament size & $1 \times 30 \mathrm{mils}$ & 43 & 0.145 \\
Ionization & Thermal & 44 & 2.06 \\
Tempcrature range & $1400-1700^{\circ} \mathrm{C}$ & 46 & 0.0033 \\
Ion measured & $\mathrm{Ca}^{+}$ & 48 & 0.185 \\
\hline
\end{tabular}

\section{Sample Loading}

Place calcium carbonate on the filament and slurry with hydriodic acid. Dry the sample with a gentle heat and drive off excess iodine; then increase the filament temperature to a dull-red heat $\left(\sim 750^{\circ} \mathrm{C}\right)$. Heating will first convert the sample to $\mathrm{CaI}_{2}$ and then to $\mathrm{CaO}$. The sample is then tightly bound to the filament.

\section{Comments}

One microgram of calcium will produce an ion current of $10^{-10}$ amp for more than $20 \mathrm{~min}$.

The $\mathrm{Ca}^{+}$beam is stable over long periods of time.

Interference from $\mathrm{K}^{40}$ is possible, and data is only taken when $\mathrm{K}^{41}$ is very much less than the major $\mathrm{Ca}$ is otope.

Interference from previous calcium samples has not been observed.

$\mathrm{CaO}, \mathrm{Ca}\left(\mathrm{NO}_{3}\right)_{2}$, or $\mathrm{CaI}_{2}$ may be used in place of $\mathrm{CaCO}_{3}$. 


\section{Cerium.}

\begin{tabular}{|c|c|c|c|}
\hline \multirow{2}{*}{\multicolumn{2}{|c|}{$\begin{array}{c}\text { Preferred Conditions } \\
\therefore\end{array}$}} & \multicolumn{2}{|c|}{$\begin{array}{l}\text { Relative Abundance } \\
\text { of Isotopes }\end{array}$} \\
\hline & & \multirow{2}{*}{$\begin{array}{c}\text { Isotope } \\
136\end{array}$} & \multirow{2}{*}{$\begin{array}{r}\text { Atom \% } \\
0.193\end{array}$} \\
\hline Compound & $\mathrm{CeO}_{2}$ & & \\
\hline Sample filament & Tantalum & 138 & 0.250 \\
\hline Filament size & $1 \times 30 \mathrm{mils}$ & 140 & 88.48 . \\
\hline Ionization & Thermal & 142 & 11.07 \\
\hline Temperature range & $1300-1600^{\circ} \mathrm{C}$ & & \\
\hline Ion measured & $\mathrm{CeO}^{+}$ & & \\
\hline
\end{tabular}

\section{Sample Looding}

Place finely. divided cerium oxide on the filament and partially digest with a drop of concentrated nitric acid. Dry the sample with a gentle heat; then increase the filament temperature to a dullred heat $\left(\sim 750^{\circ} \mathrm{C}\right)$.

\section{Comments}

One microgram of cerium produces an ion current of $10^{-10}$ amp for more than an hour.

The observed ratio of $\mathrm{Ce}^{+}$to $\mathrm{CeO}^{+}$is $1:>100$.

Interference from previous cerium samples has not been observed.

Corrections for $\mathrm{O}^{17}$ and $\mathrm{O}^{18}$ may be necessary. 
Chlorine

\begin{tabular}{ll||cc}
\hline \multicolumn{1}{c||}{ Preferred Conditions } & \multicolumn{2}{c}{$\begin{array}{c}\text { Relative Abundance } \\
\text { of Isotopes }\end{array}$} \\
\hline Compound & $\mathrm{NaCl}$ & 35 & 75.529 \\
Sample filament & Tantalum & 37 & 24.471 \\
Filament size & $1 \times 30 \mathrm{mils}$ & & \\
Ionization & Electron bombardment & & \\
Temperature range & $700-1400^{\circ} \mathrm{C}$ & \\
Ion measured & $\mathrm{NaCl}^{+}$ & \\
\hline
\end{tabular}

\section{Sample Loading}

Place sodium chloride on the filament; increase the temperature slowly until the sample melts. If the temperature is increased too rapidly the sample will "pop" off of the filament.

\section{Comments}

Interference from previous chlorine samples has not been observed at either the $\mathrm{NaCl}^{+}$or $\mathrm{Na}_{2} \mathrm{Cl}^{+}$ positions. These ions have approximately equal intensity.

Data can be taken at $\mathrm{Cl}^{+}$and $\mathrm{HCl}^{+}$; however, interference from previous samples is serious at this position.

The temperature at which $\mathrm{NaCl}^{+}$first appears is unpredictable and may vary over a wide range.

Data have been obtained using the negative ions of chlorine.

The $\mathrm{Cl}^{-}$data are relatively free from interference. 


\section{Chromium}

\begin{tabular}{|c|c|c|c|}
\hline \multicolumn{2}{|c|}{ Preferred Conditions } & \multicolumn{2}{|c|}{$\begin{array}{l}\text { Relative Abundance } \\
\text { of Is otopes }\end{array}$} \\
\hline & & \multirow{2}{*}{$\begin{array}{c}\text { Is otope } \\
50\end{array}$} & \multirow{2}{*}{$\begin{array}{l}\text { Atom \% } \\
4.31\end{array}$} \\
\hline Compound & $\mathrm{Cr}_{2} \mathrm{O}_{3}$ & & \\
\hline Sample filament & Tungsten & 52 & 83.76 \\
\hline Filament size & $1 \times 30 \mathrm{mils}$ & 53 & 9.55 \\
\hline Ionization & Thermal & 54 & 2.38 \\
\hline Temperature range & $1300-1600^{\circ} \mathrm{C}$ & & \\
\hline Ion measured & $\mathrm{Cr}^{+}$ & & \\
\hline
\end{tabular}

\section{Sample Loading}

Place finely divided chromium oxide on the filament. Introduce the loaded filament into a vacuum chamber and pump down to $<20 \mu$ pressure. Increase the filament tempreature until the sample begins to fuse.

\section{Comments}

The $\mathrm{Cr}^{+}$beam is stable over long periods of time. .

Interference from previous chromium samples has nọt been observed. . 


\section{Copper}

\begin{tabular}{|c|c|c|c|}
\hline \multicolumn{2}{|c|}{ Preferred Conditions } & \multicolumn{2}{|c|}{$\begin{array}{c}\text { Relative Abundance } \\
\text { of Isotopes }\end{array}$} \\
\hline & & \multirow{2}{*}{\begin{tabular}{|c|} 
Isotope \\
63
\end{tabular}} & \multirow{2}{*}{$\begin{array}{r}\text { Atom \% } \\
69.09\end{array}$} \\
\hline Compound & $\mathrm{CuO}$ & & \\
\hline Sample filament & Tungsten & 65 & 30.91 \\
\hline Filament size & $1 \times 30 \mathrm{mils}$ & & \\
\hline Ionization & Electron bombardment & & \\
\hline Tempcrature range & $1000-1400^{\circ} \mathrm{C}$ & & \\
\hline Iull medsuted & $\mathrm{Gu}^{+}$ & & \\
\hline
\end{tabular}

\section{Sample Loading}

Place finely divided cupric oxide on the filament and slurry with distilled water. Dry with a gentle heat. Cover with a vacuum chamber and pump down to $<20 \mu$ pressure. Increase the filament temperature until sample reduces to copper metal and melts.

\section{Comments}

Electron bombardment intensities are a factor of 10 greater than thermal intensities.

Interferencc from previous copper samples has not been observed. 
Dysprosium

\begin{tabular}{|c|c|c|c|}
\hline \multirow{2}{*}{\multicolumn{2}{|c|}{ Preferred Conditions }} & \multicolumn{2}{|c|}{$\begin{array}{c}\text { Relative Abundance } \\
\text { of Isotopes }\end{array}$} \\
\hline & & \multirow{2}{*}{$\begin{array}{c}\text { Is otope } \\
156\end{array}$} & \multirow{2}{*}{$\begin{array}{r}\text { Atom \% } \\
0.0524\end{array}$} \\
\hline Compound & $\mathrm{Dy}_{2} \mathrm{O}_{3}$ & & \\
\hline Sample filament & Tantalum & 158 & 0.0902 \\
\hline Filament size & $1 \times 30 \mathrm{mils}$ & 160 & 2.294 \\
\hline Ionization & Thermal & 161 & 18.88 \\
\hline Temperature range & $1400-1500^{\circ} \mathrm{C}$ & 162 & 25.53 \\
\hline Ion Measured & $\mathrm{Dy}^{+}$ & 163 & 24.97 \\
\hline 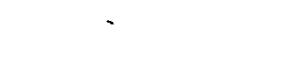 & & 164 & 28.18 \\
\hline
\end{tabular}

\section{Sample Looding}

Place finely divided dysprosium oxide on the filament and partially digest with a drop of concentrated nitric acid. Dry sample with a gentle heat; then increase the filament temperature to a dull-red heat $\left(\sim 750^{\circ} \mathrm{C}\right)$.

\section{Comments}

One microgram of dysprosium produces an ion current $00^{-10}$ amp for more than an hour.

The observed ratio of $\mathrm{Dy}^{+}$to $\mathrm{DyO}^{+}$is $10: 1$.

Interference from previous dysprosium samples has not been observed. 


\section{Erbium}

\begin{tabular}{ll||cc}
\hline \multicolumn{2}{c||}{ Preferred Conditions } & \multicolumn{2}{c}{$\begin{array}{c}\text { Relative Abundance } \\
\text { of Isotopes }\end{array}$} \\
\cline { 3 - 4 } & & Isotope & Atom \% \\
\hline Compound & $\mathrm{Er}_{2} \mathrm{O}_{3}$ & 162 & 0.136 \\
Sample filament & $\mathrm{Tantalum}$ & 164 & 1.56 \\
Filament size & $1 \times 30 \mathrm{mils}$ & 166 & 33.41 \\
Ionization & Thermal & 167 & 22.94 \\
Temperature range & $1400-1700^{\circ} \mathrm{C}$ & 168 & 27.07 \\
Ion measured & $\mathrm{Er}^{+}$ & 170 & 14.88 \\
\hline
\end{tabular}

\section{Sample Looding}

Place finely divided erbium oxide on the filament and partially digest with a drop of concentrated nitric acid. Dry sample with a gentle heat; then increase the filament temperature to a dull-red heat $\left(\sim 700^{\circ} \mathrm{C}\right)$.

\section{Comments}

One microgram of erbium produces an ion current of $10^{-10}$ amp for more than an hour.

The observed ratio of $\mathrm{Er}^{+}$to $\mathrm{ErO}^{+}$is $>100: 1$.

Interference from previous erbium samples has not been observed. 


\section{Europium}

\begin{tabular}{ll||lc}
\hline \multicolumn{2}{c||}{ Preferred Conditions } & \multicolumn{2}{c}{$\begin{array}{c}\text { Relative Abundance } \\
\text { of Isotopes }\end{array}$} \\
\hline Compound & $\mathrm{Eu}_{2} \mathrm{O}_{3}$ & 151 & Atom \% \\
\hline Sample filament & Tantalum & 153 & 47.82 \\
Filament size & $1 \times 30 \mathrm{mils}$ & & \\
Ionization & Thermal & & \\
Temperature range & $1400-1700^{\circ} \mathrm{C}$ \\
Ion measured & $\mathrm{Eu}^{+}$ & & \\
\hline
\end{tabular}

\section{Sample Looding}

Place finely divided europium -oxide on the filament and partially digest with a drop of concentrated nitric acid. Dry sample with a gentle heat; then increase the filament temperature to a dull-red heat $\left(\sim 750^{\circ} \mathrm{C}\right)$.

\section{Comments}

One microgram of europium produces an ion current of $10^{-10}$ amp for more than an hour.

The observed ratio of $\mathrm{Eu}^{+}$to $\mathrm{EuO}^{+}$is $>100: 1$.

Interference from previous europium samples has not been observed. 
Gadolinium

\begin{tabular}{ll||cc}
\hline \multicolumn{2}{c||}{ Preferred Conditions } & \multicolumn{2}{c}{$\begin{array}{c}\text { Relative Abundance } \\
\text { of Isotopes }\end{array}$} \\
\cline { 3 - 4 } & & Isotope & Atom \% \\
\hline Compound & $\mathrm{Gd}_{2} \mathrm{O}_{3}$ & 152 & 0.200 \\
Sample filament & Tantalum & 154 & 2.15 \\
Filament size & $1 \times 30 \mathrm{mils}$ & 155 & 14.73 \\
Ionization & Thermal & 156 & 20.47 \\
Temperature range & $1400-1700^{\circ} \mathrm{C}$ & 157 & 15.68 \\
Ion measured & GdU & 158 & 24.87 \\
& & 160 & 21.90 \\
\hline
\end{tabular}

\section{Sample Looding}

Place finely divided gadolinium oxide on the filament and partially digest with a drop of concentrated nitric acid. Dry sample with a gentle heat; then increase filament temperature to a dullred heat $\left(\sim 750^{\circ} \mathrm{C}\right)$.

\section{Comments}

One.microgram of gadolinium produces an ion current of $10^{-10}$ amp for more than an hour.

The observed ratio of $\mathrm{Gd}^{+}$to $\mathrm{GdO}^{+}$is $1:>100$.

Interference from previous gadolinium samples has not been observed.

Corrections for $\mathrm{O}^{17}$ and $\mathrm{O}^{18}$ may be necessary. 


\section{Gallium}

\begin{tabular}{|c|c|c|c|}
\hline \multicolumn{2}{|c|}{ Preferred Conditions } & \multicolumn{2}{|c|}{$\begin{array}{c}\text { Relative A bundance } \\
\text { of Is otopes }\end{array}$} \\
\hline \multicolumn{2}{|c|}{$\cdot \quad \therefore n^{\prime}-\cdots$} & Isotope & Atom $\%$ \\
\hline Compound & $\mathrm{Ga}_{2} \mathrm{O}_{3}$ & 69 & 60.4 \\
\hline Sample filament & Tungsten & 71 & 39.6 \\
\hline Filament size & $1 \times 30$ mils & & \\
\hline Ionization & Thermal & & \\
\hline Temperature range & $700-1200^{\circ} \mathrm{C}$ & & \\
\hline Ion measured & $\mathrm{Ga}^{+}$ & & \\
\hline
\end{tabular}

\section{Sample Loading}

Place gallium oxide on the filament and slurry with distilled water. Dry sample with a gentle heat.

\section{Comments}

The use of small samples improves the stability of the ion beam.

Interference from previous gallium samples has not been observed. 
Germanium

\begin{tabular}{|c|c|c|c|}
\hline \multicolumn{2}{|c|}{ Preferred Conditions } & \multicolumn{2}{|c|}{$\begin{array}{c}\text { Relative Abundance } \\
\text { of Isotopes }\end{array}$} \\
\hline & & \multirow{2}{*}{$\begin{array}{c}\text { Isotope } \\
70\end{array}$} & \multirow{2}{*}{$\frac{\text { Atom \% }}{20.52}$} \\
\hline Compound & $\mathrm{BaGeF}_{6}$ & & \\
\hline Sample filament & Tantalum & 72 & 27.43 \\
\hline Filament size & $1 \times 60$ mils & 73 & 7.76 \\
\hline Ionization & Electron bombardment & 74 & 36.54 \\
\hline Temperaturé rảnge & $750-1200^{\circ} \mathrm{C}$ & 76 & 7.76 \\
\hline Ion measured & $\mathrm{GeF}_{3}^{+}$or $\mathrm{GcF}^{+}$ & & \\
\hline
\end{tabular}

\section{Sample Loading}

Place barium fluogermanate on the filament and slurry with distilled water. Dry sample with a gentle heat.

\section{Comments}

$\mathrm{BaGeF}_{6}$ is prepared by dissolving $\mathrm{GeO}_{2}$ in $\mathrm{HF}$ followed by precipitation with $\mathrm{BaCl}_{2}$. The salt is isolated hy centrifugation.

Ions $\mathrm{Ge}^{+}, \mathrm{GeF}^{+}, \mathrm{GeF}_{2}{ }^{+}, \mathrm{GeF}_{3}{ }^{+}, \mathrm{GeOF}_{3}{ }^{+}$, and $\mathrm{GeOF}_{4}{ }^{+}$are noted hut the best data are obtained at $\mathrm{GeF}_{3}{ }^{+}$.

$\mathrm{SiF}_{3}{ }^{+}$usually appears in the ion spectrum but does not isotopically interfere.

If $\mathrm{Ge}^{+}$and $\mathrm{GeF}^{+}$are as intense as $\mathrm{GeF}_{3}{ }^{+}$, the compound apparently has not been prepared properly and a new sample must be submitted.

The $\mathrm{GeF}_{3}{ }^{+}$intensity will decrease soon after it first appears. Additional increase of temperature will produce a stable and higher ion current.

\begin{tabular}{cccccc}
\multicolumn{6}{c}{ Masses of Isotopic lons } \\
\cline { 1 - 4 } $\mathrm{Ge}^{+}$ & $\mathrm{GeF}^{+}$ & $\mathrm{GeF}_{2}{ }^{+}$ & $\mathrm{GeF}_{3}{ }^{+}$ & $\mathrm{GeOF}_{3}{ }^{+}$ & $\mathrm{GeOF}_{4}^{+}$ \\
\hline 70 & 89 & 108 & 127 & 143 & 163 \\
72 & 91 & 110 & 129 & 145 & 164 \\
73 & 92 & 111 & 130 & 146 & 165 \\
74 & 93 & 112 & 131 & 147 & 166 \\
76 & 95 & 114 & 133 & 149 & 168 \\
\hline
\end{tabular}


Hafnium

\begin{tabular}{ll||cr}
\hline \multicolumn{1}{c||}{ Preferred Conditions } & \multicolumn{2}{c}{$\begin{array}{c}\text { Relative Abundance } \\
\text { of Isotopes }\end{array}$} \\
\cline { 3 - 4 } & & Isotope & Atom \% \\
\hline Compound & $\mathrm{HfO}_{2}$ & 174 & 0.18 \\
Sample filament & $\mathrm{Tantalum}^{1}$ & 176 & 5.20 \\
Filament size & $1 \times 30$ mils & 177 & 18.50 \\
Ionization & Electron bombardment & 178 & 27.14 \\
Temperature range & $1700-1900^{\circ} \mathrm{C}$ & 179 & 13.75 \\
Ion measured & $\mathrm{HfO}^{+}$ & 180 & 35.24 \\
\hline
\end{tabular}

\section{Sample Loading}

Place finely divided hafnium oxide on the filament and slurry with distilled water. Dry sample with a gentle heat. Cover with a vacuum chamber and pump down to $<20 \mu$ pressure. Increase filament temperature until the sample begins to reduce to hafnium metal and melts. Do not completely convert to hafnium metal.

\section{Comments}

The observed ratio of $\mathrm{Hf}^{+}$to $\mathrm{HfO}^{+}$is approximately $1: 5$.

Thermal ion intensities are very low compared to electron-bombardment intensities.

$\mathrm{Ta}^{+}, \mathrm{TaO}^{+}$, and $\mathrm{W}$ can give interference. Interference from previous hafnium samples has not been observed.

Corrections for $\mathrm{O}^{17}$ and $\mathrm{O}^{18}$ may be necessary. 
Holmium

\begin{tabular}{ll||cc}
\hline \multicolumn{1}{c||}{ Preferred Conditions } & \multicolumn{2}{c}{$\begin{array}{c}\text { Relative Abundance } \\
\text { of Isotopes }\end{array}$} \\
\cline { 3 - 3 } & & Is otope & 100 \\
Compound & $\mathrm{Ho}_{2} \mathrm{O}_{3}$ & & \\
Sample filament & Tantalum & \\
Filament size & $1 \times 30 \mathrm{mils}$ \\
Ionization & Thermal \\
Temperature range & $1400-1600^{\circ} \mathrm{C}$ \\
Ion measured & $\mathrm{Ho}^{+}$ & \\
\hline
\end{tabular}

\section{Somple Loading}

Place finely divided holmium oxide on the filament and partially digest with a drop of concentrated nitric acid. Dry sample with a gentle heat; then increase filament temperature to a dullred heat $\left(\sim 750^{\circ} \mathrm{C}\right)$.

\section{Comments}

One microgram of holmium produces an ion current of $10^{-10}$ amp for more than an hour.

The observed ratio of $\mathrm{Ho}^{+}$to $\mathrm{HoO}^{+}$is $10: 1$.

Interference from previous holmium samples has not been observed. 


\begin{tabular}{|c|c|c|c|}
\hline \multirow{2}{*}{\multicolumn{2}{|c|}{ Preferred Conditions }} & \multicolumn{2}{|c|}{$\begin{array}{c}\text { Relative Abundance } \\
\text { of Isotopes }\end{array}$} \\
\hline & & Is otope & Atom $\%$ \\
\hline Compound & $\operatorname{In}_{2} \mathrm{O}_{3}$ & 113 & $=4.28$ \\
\hline Sample filament & Tantalum & 115 & 95.72 \\
\hline Filament size & $2 \times 60$ mils & & \\
\hline Ionization & Thermal & & \\
\hline Temperature range & $700-1000^{\circ} \mathrm{C}$ & . & \\
\hline Ion measured & $\mathrm{In}^{+}$ & & \\
\hline
\end{tabular}

\section{Sample Looding}

Place indium oxide on the filament and slurry with distilled water. Dry sample with a gentle heat.

\section{Comments}

The temperature must be increased slowly because excessive heat generally produces an erratic beam.

When $\mathrm{In}^{+}$first appears, the intensity will increase slowly for a few minutes and then rapidly. Filament temperature must be reduced to avoid losing the sample.

$\mathrm{InO}^{+}$appears briefly at low temperatures, but decreases as $\mathrm{In}^{+}$increases.

Interference from previous indium samples is a problem. 
lodine

\begin{tabular}{|c|c|c|c|}
\hline \multicolumn{2}{|c|}{ Preferred Conditions } & \multicolumn{2}{|c|}{$\begin{array}{c}\text { Relative Abundance } \\
\text { of Isotopes }\end{array}$} \\
\hline & & Isotope & Atom \% \\
\hline Compound & $\mathrm{NaI}$ & \multirow[t]{6}{*}{127} & \multirow[t]{6}{*}{100} \\
\hline Sample filament & Tantalum & & \\
\hline Filament size & $2 \times 60 \mathrm{mils}$ & & \\
\hline Ionization & Electron bombardment & & \\
\hline Temperature range & $<200^{\circ} \mathrm{C}$ & & \\
\hline Ion measured & $\mathrm{NaI}^{+}$ & & \\
\hline
\end{tabular}

\section{Sample Looding}

Place the sodium iodide solution on the filament and dry with a gentle heat.

\section{Comments}

Data can be obtained from $<1 \mu \mathrm{g}$ of iodine.

Temperature must be increased slowly because excessive heat generally produces an erratic beam. Interference from previous iodine samples is a very serious problem.

This procedure has frequently been used for $I^{125}, I^{127}$, and $I^{129}$. 
Iridium

\begin{tabular}{|c|c|c|c|}
\hline \multirow[t]{2}{*}{$P$} & Preferred Conditions & \multicolumn{2}{|c|}{$\begin{array}{c}\text { Relative Abundance } \\
\text { of Isotopes }\end{array}$} \\
\hline & & Isotope & Atom $\%$ \\
\hline Compound & Ir & 191 & 37.3 \\
\hline Sample filament & Tungsten & 193 & $62: 7$ \\
\hline Filament size & $1 \times 30$ mils & . & \\
\hline Ionization & Electron bombardment & & \\
\hline Temperature range & $1500-1800^{\circ} \mathrm{C}$ & . & \\
\hline Ion measured & $\mathrm{Ir}^{+}$ & & \\
\hline
\end{tabular}

\section{Somple Looding}

Place finely divided iridium metal on the filament. Cover with a vacuum chamber and pump down to $<20 \mu$ pressure. Increase filament temperature until sample begins to melt.

\section{Comments}

A large sample is required $(>1 \mathrm{mg})$.

Optimum temperature must be approached very slowly after $\mathrm{Ir}^{+}$first appears.

Interference from previous iridium samples has not been observed.

Data were not obtained when using a tantalum filament. 
Iron

\begin{tabular}{|c|c|c|c|}
\hline \multicolumn{2}{|c|}{ Preferred Conditions } & \multicolumn{2}{|c|}{$\begin{array}{c}\text { Relative Abundance } \\
\text { of Isotopes }\end{array}$} \\
\hline & & Isotope & Atom $\%$ \\
\hline Compound & $\mathrm{Fe}_{2} \mathrm{O}_{3}$ & 54 & 5.82 \\
\hline Sample filament & Tantalum & 56 & 91.66 \\
\hline Filament size & $2 \times 60 \mathrm{mils}$ & 57 & 2.19 \\
\hline Ionization & Electron bombardment & 58 & 0.33 \\
\hline Temperature range & $<200^{\circ} \mathrm{C}$ & & \\
\hline Ion measured & $\mathrm{FeI}^{+}$ & & \\
\hline
\end{tabular}

\section{Sample Looding}

Place iron oxide on the filament and add hydriodic acid. Dry sample with a gentle heat; then increase the temperature slowly until sample melts. Melting the iron iodide will require $\sim 4 \mathrm{amp}$ when heated in air.

\section{Comments}

$\mathrm{FeI}_{2}$ is very hygruscopic.

Interference from previous iron iodide samples is a very serious problem.

$\mathrm{Fe}$ metal can be ionized thermally, but ion intensities are relatively low compared to electron bombardment. $\mathrm{Fe}_{2} \mathrm{O}_{3}$ can be converted to $\mathrm{Fe}$ metal as follows: Load finely divided iron oxide on a tantalum filament. Cover with a vacuum chamber and pump down to $<20 \mu$ pressure. Increase temperature until the sample melts. A temperature range of $1200-1400^{\circ} \mathrm{C}$ is required to obtain $\mathrm{Fe}^{+}$.

$\mathrm{Mn}^{+}$is frequently observed in the ion spectrum but does not interfere.

$\mathrm{FeCl}_{2}$ has been used for analysis.

\begin{tabular}{ccc}
\multicolumn{3}{c}{ Masses of Is otopic lons } \\
\hline $\mathrm{Fe}^{+}$ & $\mathrm{FeI}^{+}$ & $\mathrm{FeI}_{2}{ }^{+}$ \\
\hline 54 & 181 & 308 \\
56 & 183 & 310 \\
57 & 184 & 311 \\
58 & 185 & 312 \\
\hline
\end{tabular}


Lanthanum

\begin{tabular}{ll||rr}
\hline \multicolumn{1}{c||}{ Preferred Conditions } & \multicolumn{2}{c}{$\begin{array}{c}\text { Relative Abundance } \\
\text { of Isotopes }\end{array}$} \\
\cline { 3 - 3 } & & Isotope & Atom \% \\
\hline Compound & $\mathrm{La}_{2} \mathrm{O}_{3}$ & 138 & 0.089 \\
Sample filament & Tantalum & 139 & 99.911 \\
Filament size & $1 \times 30 \mathrm{mils}$ & & \\
Ionization & Thermal & & \\
Temperature range & $1300-1600^{\circ} \mathrm{C}$ \\
Ion measured & $\mathrm{LaO}^{+}$ & & \\
\hline
\end{tabular}

\section{Sample Loading}

Place finely divided lanthanum oxide on the filament and partially digest with concentrated nitric acid. Dry sample with a gentle heat; then increase filament temperature to a dull-red heat $\left(\sim 750^{\circ} \mathrm{C}\right)$.

\section{Comments}

One microgram of lanthanum produces an ion current of $10^{-10} \mathrm{amp}$ for an hour.

The observed ratio of $\mathrm{La}^{+}$to $\mathrm{LaO}^{+}$is $1:>100$.

Interference from previous lanthanum samples has not been observed.

Correction for $\mathrm{O}^{17}$ may be necessary. 


\section{Lead}

\begin{tabular}{ll||cc}
\hline \multicolumn{1}{c||}{ Preferred Conditions } & \multicolumn{2}{c}{$\begin{array}{c}\text { Relative Abundance } \\
\text { of Isotopes }\end{array}$} \\
\cline { 3 - 4 } & & Isotope & Atom \% \\
\hline Compound & $\mathrm{Pb}\left(\mathrm{NO}_{3}\right)_{2}$ & 204 & 1.48 \\
Sample filament & Tungsten & 206 & 23.6 \\
Filament size & $1 \times 30 \mathrm{mils}$ & 207 & 22.6 \\
Ionization & Thermal & 208 & 52.3 \\
Temperature range & $1000-1400^{\circ} \mathrm{C}$ & & \\
Ion measured & $\mathrm{Pb}^{*}$ & & \\
\hline
\end{tabular}

\section{Sample Loading}

Place the lead nitrate solution on the filament and add a drop of saturated boric acid solution. Dry this mixture with a gentle heat; then increase filament temperature to a dull-red heat $\left(\sim 750^{\circ} \mathrm{C}\right)$.

\section{Comments}

Analyses have been made on less than $10 \mu \mathrm{g}$ of lead.

Interference from previous lead samples has not been observed.

$\mathrm{PbO}$ or $\mathrm{PbCrO}_{4}$ can be ionized with electron bombardment. These compounds should be loaded on tantalum filaments and data taken at $\mathrm{Pb}^{+}$. 


\section{Lithium}

\begin{tabular}{|c|c|c|c|}
\hline \multirow{2}{*}{\multicolumn{2}{|c|}{ Preferred Conditions }} & \multicolumn{2}{|c|}{$\begin{array}{c}\text { Relative Abundance } \\
\text { of Isotopes }\end{array}$} \\
\hline & & \multirow{2}{*}{$\begin{array}{c}\text { Isotope } \\
6\end{array}$} & \multirow{2}{*}{$\begin{array}{r}\text { Atom \% } \\
7.42\end{array}$} \\
\hline Compound & LiI & & \\
\hline Sample filament & Tantalum & 7 & 92.58 \\
\hline Filament size & $2 \times 60 \mathrm{mils}$ & & \\
\hline Ionization & Electron bombardment & & \\
\hline Temperature range & $<500^{\circ} \mathrm{C}$ & & \\
\hline Ion measured & $\mathrm{Li}_{2} \mathrm{I}^{+}$ & & \\
\hline
\end{tabular}

\section{Sample Loading}

Place lithium iodide solution on the filament and dry with a gentle heat.

\section{Comments}

Most Li salts can be converted to LiI with the addition of hydriodic acid.

$\mathrm{Li}$ salts $\left(\mathrm{Li}_{2} \mathrm{SO}_{4}, \mathrm{Li}_{2} \mathrm{CO}_{3}\right.$, and $\left.\mathrm{LiOH}\right)$ can be ionized thermally and analysis made at $\mathrm{Li}^{+}$. This can induce errors due to the large percentage difference in mass.

Interference from previous lithium samples is a serious problem.

$\begin{array}{cc}\text { Mass } & \text { lon } \\ 139 & \left(\mathrm{Li}^{6} \mathrm{Li}^{6} \mathrm{I}^{127}\right)^{+} \\ 140 & \left(\mathrm{Li}^{6} \mathrm{Li}^{7} \mathrm{I}^{127}\right)^{+} \\ 141 & \left(\mathrm{Li}^{7} \mathrm{Li}^{7} \mathrm{I}^{127}\right)^{+}\end{array}$




\section{Lutetium}

\begin{tabular}{|c|c|c|c|}
\hline \multicolumn{2}{|c|}{ Preferred Conditions } & \multicolumn{2}{|c|}{$\begin{array}{c}\text { Relative Abundance } \\
\text { of Isotopes }\end{array}$} \\
\hline \multicolumn{2}{|l|}{. } & Isotope & Atom $\%$ \\
\hline Compound & $\mathrm{Lu}_{2} \mathrm{O}_{3}$ & 175 & 97.41 \\
\hline Sample filament & Tantalum & 176 & 2.59 \\
\hline Filament size & $1 \times 30 \mathrm{mils}$ & & \\
\hline Ionization & Thermal & & \\
\hline Temperature range & $1400-1800^{\circ} \mathrm{C}$ & & \\
\hline Ion measured & $\mathrm{Lu}^{+}$ & & \\
\hline
\end{tabular}

\section{Sample Loading}

Place finely divided lutetium oxide on the filament and partially digest with concentrated nitric acid. Dry sample with a gentle heat; then increase filament temperature to a dull-red heat $\left(\sim 750^{\circ} \mathrm{C}\right)$.

\section{Comments}

One microgram of lutctium produces an inn current of $10^{-10}$ amp for more than an hour. The observed ratio of $\mathrm{Lu}^{+}$to $\mathrm{LuO}^{+}$is $>100: 1$.

Interference from previous lutetium samples has not been observed. 


\begin{tabular}{ll||lc}
\hline \multicolumn{2}{c}{ Magnesium } \\
\hline \multicolumn{2}{c||}{ Preferred Conditions } & \multicolumn{2}{c}{$\begin{array}{c}\text { Relative Abundance } \\
\text { of Is otopes }\end{array}$} \\
\hline Compound & $\mathrm{MgO}$ & 24 & Atom \% \\
Sample filament & Tungsten & 25 & 10.70 \\
Filament size & $1 \times 30 \mathrm{mils}$ & 26 & 11.17 \\
Ionization & Thermal & & \\
Temperature range & $1400-1500^{\circ} \mathrm{C}$ & & \\
Ion measured & $\mathrm{Mg}^{+}$ & & \\
\hline
\end{tabular}

\section{Sample Loading}

Place finely divided magnesium oxide on filament and slurry with distilled water. Dry sample with a gentle heat.

\section{Comments}

The optimum temperature must be approached very slowly after $\mathrm{Mg}^{+}$first appears.

If $\mathrm{Na}^{23}$ or $\mathrm{Al}^{27}$ impurity ions are of sufficient intensity, the "tails" of these beams may interfere at the $\mathrm{Mg}^{24}$ or $\mathrm{Mg}^{26}$ mass positions.

Interference from previous magnesium samples has not been observed. 


\begin{tabular}{ll||cc}
\multicolumn{2}{c}{ Mercury } \\
\hline \multicolumn{1}{c||}{ Preferred Conditions } & \multicolumn{2}{c}{$\begin{array}{c}\text { Relative Abundance } \\
\text { of Isotopes }\end{array}$} \\
\cline { 3 - 4 } & & 196 & Atom \% \\
\hline Compound & $\mathrm{Hg}\left(\mathrm{NO}_{3}\right)_{2}$ & 198 & 0.146 \\
Sample filament & Tantalum & 199 & 10.02 \\
Filament size & $2 \times 60$ mils & 200 & 16.84 \\
Ionization & Electron bombardment & 201 & 23.13 \\
Temperature range & $<500^{\circ} \mathrm{C}$ & 202 & 13.22 \\
Ion measured & $\mathrm{Hg}^{\prime}$ & 204 & 29.80 \\
& & & 6.85 \\
\hline
\end{tabular}

\section{Sample Loading}

Place mercuric nitrate solution on the filament and dry with a gentle heat.

\section{Comments}

Interference from previous mercury samples has been observed.

Samples of $<2 \mathrm{mg}$ of mercury in gold foil can be loaded by crimping the $2 \times 60$ mil tantalum filament around a sliver of foil.

Data have been obtained from mercuric sulfide. 
Molybdenum

\begin{tabular}{|c|c|c|c|}
\hline \multicolumn{2}{|c|}{ Preferred Conditions } & \multicolumn{2}{|c|}{$\begin{array}{c}\text { Relative Abundance } \\
\text { of Isotopes }\end{array}$} \\
\hline & & Isotope & Atom $\%$ \\
\hline Compound & $\mathrm{MoO}_{3}$ & 92 & 15.84 \\
\hline Sample filament & Tungsten & 94 & 9.04 \\
\hline Filament size & $1 \times 30$ mils & 95 & 15.72 \\
\hline Ionization & Electron bombardment & 96 & 16.53 \\
\hline Temperature range & $700-1000^{\circ} \mathrm{C}$ & 97 & 9.46 \\
\hline \multirow[t]{2}{*}{ Ion measured } & $\mathrm{MoO}_{2}^{+}$ & 98 & 23.78 \\
\hline & & 100 & 9.63 \\
\hline
\end{tabular}

\section{Sample Loading}

Place finely divided molybdenum oxide on the filament and slurry with distilled water. Dry sample with a gentle heat.

\section{Comments}

The following ions are observed: $\mathrm{Mo}^{+}, \mathrm{MoO}^{+}, \mathrm{MoO}_{2}{ }^{+}$, and $\mathrm{MoO}_{3}{ }^{+}$, with an intensity ratio of 2,5 , 10 , and 3 respectively.

Thermal intensities are very low compared to electron-bombardment intensities.

Interference from previous molybdenum samples has not been observed.

Corrections for $\mathrm{O}^{17}$ and $\mathrm{O}^{18}$ may be necessary.

\begin{tabular}{rrrr}
\multicolumn{4}{c}{ Mosses of Isotopic lons } \\
\hline $\mathrm{Mo}^{+}$ & $\mathrm{MoO}^{+}$ & $\mathrm{MoO}_{2}{ }^{+}$ & $\mathrm{MoO}_{3}{ }^{+}$ \\
\hline 92 & 108 & 124 & 140 \\
94 & 110 & 126 & 142 \\
95 & 111 & 127 & 143 \\
96 & 112 & 128 & 144 \\
97 & 113 & 129 & 145 \\
98 & 114 & 130 & 146 \\
100 & 116 & 132 & 148 \\
\hline
\end{tabular}


Neodymium

\begin{tabular}{ll||cr}
\hline \multicolumn{1}{c||}{ Preferred Conditions } & \multicolumn{2}{c}{$\begin{array}{c}\text { Relative Abundance } \\
\text { of Isotopes }\end{array}$} \\
\cline { 3 - 4 } & & Isotope & Atom \% \\
\hline Compound & $\mathrm{Nd}_{2} \mathrm{O}_{3}$ & 142 & 27.11 \\
Sample filament & Tantalum & 143 & 12.17 \\
Filament size & $1 \times 30 \mathrm{mils}$ & 144 & 23.85 \\
Ionization & Thermal & 145 & 8.30 \\
Temperature range & $1300-1600^{\circ} \mathrm{C}$ & 146 & 17.22 \\
Ion measured & $\mathrm{NdO}^{+}$ & 148 & 5.73 \\
& & 150 & 5.62 \\
\hline
\end{tabular}

\section{Sample Loading}

Place finely divided neodymium oxide on the filament and partially digest with concentrated nitric acid. Dry sample with a gentle heat; then increase filament temperature to a dull-red heat $\left(\sim 750^{\circ} \mathrm{C}\right)$.

\section{Comments}

One microgram of neodymium produces an ion current of $10^{-10}$ amp for more than an hour.

The observed ratio of $\mathrm{Nd}^{+}$to $\mathrm{NdO}^{+}$is $1:>100$.

Interference from previous neodymium samples has not been observed.

Corrections for $\mathrm{O}^{17}$ and $\mathrm{O}^{13}$ may be necessary. 
Neptunium

\begin{tabular}{ll||cc}
\hline \multicolumn{1}{c||}{ Preferred Conditions } & \multicolumn{2}{c}{$\begin{array}{c}\text { Relative Abundance } \\
\text { of Is otopes }\end{array}$} \\
\hline Compound & $\mathrm{NpO}_{2}\left(\mathrm{NO}_{3}\right)_{2}$ & Atom \% \\
Sample filament & Tantalum & 237 & \\
Filament size & $1 \times 30 \mathrm{mils}$ \\
Ionization & Thermal \\
Temperature range & $1700-1900^{\circ} \mathrm{C}$ \\
Ion measured & $\mathrm{NpO}_{2}{ }^{+}$ & \\
\hline
\end{tabular}

\section{Sample Loading}

Place the neptunium nitrate solution on the filament and dry with a gentle heat.

\section{Comments}

The observed ratio of $\mathrm{Np}^{+}: \mathrm{NpO}^{+}: \mathrm{NpO}_{2}{ }^{+}$is approximately $<1: 10: 20$. 
Nickel

\begin{tabular}{ll||cc}
\hline \multicolumn{1}{c||}{ Preferred Conditions } & \multicolumn{2}{c}{$\begin{array}{c}\text { Relative Abundance } \\
\text { of Isotopes }\end{array}$} \\
\cline { 3 - 3 } & & Isotope & Atom \% \\
\hline Compound & $\mathrm{Ni}$ & 58 & 67.88 \\
Fample filament & Tungsten & 60 & 26.23 \\
Ionization & $1 \times 30$ mils & 61 & 1.19 \\
Temperature range & Electron bombardment & 62 & 3.66 \\
lon measured & $1000-1400^{\circ} \mathrm{C}$ & 64 & 1.08 \\
\hline
\end{tabular}

\section{Sample Loading}

Place finely divided nickel metal on the filament. Cover with a vacuum chamber and pump down to $<20 \mu$ pressure. Increase filament temperature until sample melts.

\section{Comments}

A serious background peak is frequently found at mass 64 . This is eliminated by baking the loaded filament at approximately $850^{\circ} \mathrm{C}$ overnight.

Thermal ionization intensities are very low $(<1: 10)$ compared to those produced by electron bombardment.

Interference from previous nickel samples has not been observed. 


\begin{tabular}{|c|c|c|c|}
\hline \multicolumn{2}{|c|}{ Preferred Conditions } & \multicolumn{2}{|c|}{$\begin{array}{l}\text { Relative Abundance } \\
\text { of Isotopes }\end{array}$} \\
\hline & & \multirow{2}{*}{$\begin{array}{c}\text { Isotope } \\
184\end{array}$} & \multirow{2}{*}{$\begin{array}{r}\text { Atom \% } \\
0.018\end{array}$} \\
\hline Compound & $\mathrm{OsO}_{2} \cdot \mathrm{XH}_{2} \mathrm{O}$ & & \\
\hline Sample filament & Tantalum & 186 & 1.59 \\
\hline Filament size & $2 \times 60$ mils & 187 & 1.64 \\
\hline Ionization & Electron bombardment & 188 & 13.3 \\
\hline Temperature range & $<500^{\circ} \mathrm{C}$ & 189 & 16.1 \\
\hline \multirow[t]{2}{*}{ Ion measured } & $\mathrm{OsO}_{4}{ }^{+}$ & 190 & 26.4 \\
\hline & & 192 & 41.0 \\
\hline
\end{tabular}

\section{Sample Loading}

Place finely divided hydrated osmium dioxide on the filament and slurry with distilled water. Dry sample with a gentle heat.

\section{Comments}

$\mathrm{OsO}_{4}$ melts at $45^{\circ}$ and boils at $100^{\circ} \mathrm{C}$, yielding a very poisonous vapor which causes pathological disturbances, even to the extent of blindness.

The optimum temperature must be approached very slowly after $\mathrm{OsO}_{4}{ }^{+}$first appears.

The following ions are observed: $\mathrm{Os}^{+}, \mathrm{OsO}^{+}, \mathrm{OsO}_{2}{ }^{+}, \mathrm{OsO}_{3}{ }^{+}$, and $\mathrm{OsO}_{4}{ }^{+}$with an intensity ratio of $3,2,4,3$, and 10 respectively.

Interference from previous samples is a problem. Corrections for $\mathrm{O}^{17}$ and $\mathrm{O}^{18}$ may be necessary.

\begin{tabular}{ccccc}
\multicolumn{5}{c}{ Masses of Isotopic lons } \\
\hline $\mathrm{Os}^{+}$ & $\mathrm{OsO}^{+}$ & $\mathrm{OsO}_{2}{ }^{+}$ & $\mathrm{OsO}_{3}{ }^{+}$ & $\mathrm{OsO}_{4}^{+}$ \\
\hline 184 & 200 & 216 & 232 & 248 \\
186 & 202 & 218 & 234 & 250 \\
187 & 203 & 219 & 235 & 251 \\
188 & 204 & 220 & 236 & 252 \\
189 & 205 & 221 & 237 & 253 \\
190 & 206 & 222 & 238 & 254 \\
192 & 208 & 224 & 240 & 256 \\
\hline
\end{tabular}


Palladium

\begin{tabular}{ll||cc}
\hline \multicolumn{1}{c||}{ Preferred Conditions } & \multicolumn{2}{c}{$\begin{array}{c}\text { Relative Abundance } \\
\text { of Isotopes }\end{array}$} \\
\cline { 3 - 4 } & & Isotope & Atom \% \\
\hline Compound & Pd & 102 & 0.96 \\
Filample filament & Iridium or rhenium & 104 & 10.97 \\
Ionization & $1 \times 30$ mils & 105 & 22.23 \\
Temperature range & $>1000^{\circ} \mathrm{C}$ & 106 & 27.33 \\
Ion measured & $\mathrm{Pd}^{+}$ & 108 & 26.71 \\
\hline
\end{tabular}

\section{Sample Looding}

Place finely divided palladium metal on the filament. Cover with a vacuum chamber and pump down to $<20 \mu$ pressure. Increase filament temperature until sample melts.

\section{Comments}

The $\mathrm{Pd}^{+}$beam is stable over long periods of time. Interference from previous palladium samples has not been observed. 
Platinum

\begin{tabular}{ll||cc}
\hline \multicolumn{1}{c||}{ Preferred Conditions } & \multicolumn{2}{c}{$\begin{array}{c}\text { Relative Abundance } \\
\text { of Isotopes }\end{array}$} \\
\cline { 3 - 4 } & & Isotope & Atom \% \\
\hline Compound & $\mathrm{Pt}$ & 190 & $\mathbf{0 . 0 1 2 7}$ \\
Sample filament & Tungsten & 192 & 0.78 \\
Filament size & $1 \times 30$ mils & 194 & 32.9 \\
Ionization & Electron bombardment & 195 & 33.8 \\
Temperature range & $900-1500^{\circ} \mathrm{C}$ & 196 & 25.3 \\
Ion measured & $\mathrm{Pt}^{+}$ & 198 & 7.21 \\
\hline
\end{tabular}

\section{Somple Loading}

Place finely divided platinum metal on the filament. Cover with a vacuum chamber and pump down to $<20 \mu$ pressure. Increase filament temperature until sample melts.

\section{Comments}

$\mathrm{WO}^{+}$frequently appears. As the intensity of $\mathrm{WO}^{+}$begins to decrease $\mathrm{Pt}^{+}$will appear.

$\mathrm{Hg}^{+}$and $\mathrm{WO}^{+}$can give interference. Interference from previous platinum samples has not been observed.

Data were not obtained when using a tantalum filament. 


\begin{tabular}{ll||cc}
\multicolumn{2}{c}{ Potassium } \\
\multicolumn{2}{c||}{ Preferred Conditions } & \multicolumn{2}{c}{$\begin{array}{c}\text { Relative Abundance } \\
\text { of Isotopes }\end{array}$} \\
\cline { 3 - 3 } & & $\mathrm{K}_{3} \mathrm{PO}_{4}$ & Atom \% \\
\hline Compound & Tantalum & 39 & 93.10 \\
Sample filament & $1 \times 30 \mathrm{mils}$ & 40 & 0.01181 \\
Filament size & Thermal & 41 & 6.88 \\
Ionization & $600-800^{\circ} \mathrm{C}$ & & \\
Temperature range & $\mathrm{K}^{+}$ & & \\
Ion measured & & & \\
\hline
\end{tabular}

\section{Sample Loading}

Place potassium solution on the filament and dry with a gentle heat.

\section{Comments}

All tantalum filaments contain residual potassium. The major part of the impurities can be removed by prebaking the filament at $6.0 \mathrm{amp}$ for $2 \mathrm{~min}$ at a pressure of $<5 \times 10^{-5}$ torr.

Data have been obtained on $<1 \mu \mathrm{g}$ of potassium.

Temperature must be increased slowly because excessive heat generally produces an erratic beam.

Interference from previous potassium samples is a very serious problem. 
Praseodymium

\begin{tabular}{ll||cc}
\hline \multicolumn{2}{c||}{ Preferred Conditions } & \multicolumn{2}{c}{$\begin{array}{c}\text { Relative Abundance } \\
\text { of Isotopes }\end{array}$} \\
\cline { 3 - 3 } Compound & $\mathrm{Pr}_{2} \mathrm{O}_{3}$ & 141 & Atom \% \\
Sample filament & Tantalum & & \\
Filament size & $1 \times 30 \mathrm{mils}$ \\
Ionization & Thermal & \\
Temperature range & $130 \dot{0}^{-1600^{\circ} \mathrm{C}}$ \\
Ion measured & $\mathrm{PrO}^{+}$ & \\
\hline
\end{tabular}

\section{Sample Looding}

Place finely divided praseodymium oxide on the filament and partially digest with concentrated nitric acid. Dry sample with a gentle heat; then increase filament temperature to a dull-red heat $\left(\sim 750^{\circ} \mathrm{C}\right)$.

\section{Comments}

One microgram of praseodymium produces an ion current of $10^{-10}$ a mp for more than an hour. The observed ratio of $\mathrm{Pr}^{+}$to $\mathrm{PrO}^{+}$is $1:>100$.

Interference from previous praseodymium samples has not been observed. 
Rhenium

\begin{tabular}{ll||cc}
\hline & & \multicolumn{2}{c}{$\begin{array}{c}\text { Relative Abundance } \\
\text { of Isotopes }\end{array}$} \\
\cline { 3 - 3 } & Preferred Conditions & Isotope & Atom \% \\
\hline Cumpound & $\mathrm{NH}_{4} \mathrm{Re}_{2} \mathrm{O}_{7}$ & 185 & 37.07 \\
Sample filament & Tantalum & 187 & 62.93 \\
Filament size & $2 \times 60 \mathrm{mils}$ \\
Ionization & Electron bombardment & & \\
Temperature range & $<200^{\circ} \mathrm{C}$ & & \\
Ion measured & $\mathrm{Re}^{+}$ & & \\
\hline
\end{tabular}

\section{Sample Looding}

Place ammonium perrhenate on the filament and slurry with distilled water. Dry sample with a gentle heat.

\section{Comments}

In addition to $\mathrm{Re}^{+}$the following ions are observed: $\mathrm{ReO}^{+}, \mathrm{ReO}_{2}{ }^{+}, \mathrm{ReO}_{3}{ }^{+}$, and $\mathrm{ReO}_{4}{ }^{+}$. Each of these ions can unite with $\mathrm{H}$ to give an additional peak one mass higher.

Interference from previous rhenium samples is a problem.

Masses of Isotopic lons

\begin{tabular}{lcccc}
\hline $\mathrm{Re}^{+}$ & $\mathrm{ReO}^{+}$ & $\mathrm{ReO}_{2}{ }^{+}$ & $\mathrm{ReO}_{3}{ }^{+}$ & $\mathrm{ReO}_{4} \mathrm{H}^{+}$ \\
\hline 185 & 201 & 217 & 233 & 250 \\
187 & 203 & 219 & 235 & 252 \\
\hline
\end{tabular}


Rubidium

\begin{tabular}{ll||cc}
\hline \multicolumn{1}{c||}{ Preferred Conditions } & \multicolumn{2}{c}{$\begin{array}{c}\text { Relative Abundance } \\
\text { of Isotopes }\end{array}$} \\
\cline { 3 - 3 } & & Isotope & Atom \% \\
\hline Compound & $\mathrm{RbCl}$ & 85 & 72.15 \\
Sample filament & Tantalum & 87 & 27.85 \\
$\begin{array}{l}\text { Filament size } \\
\text { Ionization } \\
\text { Temperature range }\end{array}$ & $1 \times 30 \mathrm{mils}$ \\
Ion measured & Thermal & & \\
\hline
\end{tabular}

\section{Sample Looding}

Place the rubidium chloride solution on the filament and dry with a gentle heat.

\section{Comments}

Most tantalum filaments contain residual rubidium. The major part of the impurities can be removed by prebaking the filament at $6.0 \mathrm{amp}$ for $1.5 \mathrm{~min}$ at a pressure of $\left\langle 5 \times 10^{-5}\right.$ torr.

Data have been obtained on $<1 \mu \mathrm{g}$ of rubidium.

Interference from previous rubidium samples is a very serious problem. 
Ruthenium

\begin{tabular}{ll||cc}
\hline \multicolumn{1}{l||}{ Preferred Conditions } & \multicolumn{2}{c}{$\begin{array}{c}\text { Relative Abundance } \\
\text { of Isotopes }\end{array}$} \\
\cline { 3 - 4 } & & Is otope & Atom \% \\
\hline Compound & Ru & 96 & 5.51 \\
Sample filament & Tungsten & 98 & 1.87 \\
Filament size & $1 \times 30 \mathrm{mils}$ & 99 & 12.72 \\
Ionization & Thermal & 100 & 12.62 \\
Temperature range & $1600-2000^{\circ} \mathrm{C}$ & 101 & 17.07 \\
Ion measured & $\mathrm{Ru}^{+}$ & 102 & 31.61 \\
& & 104 & 18.58 \\
\hline
\end{tabular}

\section{Somple Looding}

Place finely divided ruthenium metal on the filament. Cover with a vacuum chamber and pump down to $<20 \mu$ pressure. Increase temperature until sample melts.

\section{Comments}

The optimum temperature must be approached very slowly after $\mathrm{Ru}^{+}$first appears

Ru metal will alloy with the tungsten filament, causing it to melt. The Ru ${ }^{+}$beam becomes unstable just before this occurs.

Interference from previous ruthenium samples has not been observed. 
Samarium

\begin{tabular}{ll||cr}
\hline \multicolumn{1}{c||}{ Preferred Conditions } & \multicolumn{2}{c}{$\begin{array}{c}\text { Relative Abundance } \\
\text { of Isotopes }\end{array}$} \\
\cline { 3 - 4 } & & Isotope & Atom \% \\
\hline Compound & $\mathrm{Sm}_{2} \mathrm{O}_{3}$ & 144 & 3.09 \\
Sample filament & Tantalum & 147 & 14.97 \\
Filament size & $1 \times 30 \mathrm{mils}$ & 148 & 11.24 \\
Ionization & Thermal & 149 & 13.83 \\
Temperature range & $1400-1700^{\circ} \mathrm{C}$ & 150 & 7.44 \\
Ion measured & $\mathrm{Sm}^{+}$ & 152 & 26.72 \\
& & 154 & 22.71 \\
\hline
\end{tabular}

\section{Sample Loading}

Place finely divided samarium oxide on the filament and partially digest with concentrated nitric acid. Dry sample with a gentle heat; then increase filament temperature to a dull-red heat $\left(\sim 750^{\circ} \mathrm{C}\right)$

\section{Comments}

One microgram of samarium produces an ion current of $10^{-10}$ amp for more than an hour.

The observed ratio of $\mathrm{Sm}^{+}$to $\mathrm{SmO}^{+}$is $>100: 1$.

Interference from previous samarium samples has not been observed. 
Selenium

\begin{tabular}{|c|c|c|c|}
\hline \multicolumn{2}{|c|}{ Preferred Conditions } & \multicolumn{2}{|c|}{$\begin{array}{c}\text { Relative Abundance } \\
\text { of Isotopes }\end{array}$} \\
\hline & & Isotope & Atom $\%$ \\
\hline Compound & $\mathrm{PbSeO}_{4}$ & 74 & 0.87 \\
\hline Sample filament & Tantalum & 76 & 9.02 \\
\hline Filament size & $2 \times 60 \mathrm{mils}$ & 77 & 7.58 \\
\hline Ionization & Electron bombardment & 78 & 23.52 \\
\hline Temperature range & $400-700^{\circ} \mathrm{C}$ & 80 & 49.82 \\
\hline Ion measured & $\mathrm{SeO}_{2}{ }^{\mathrm{I}}$ & 82 & 9.19 \\
\hline
\end{tabular}

\section{Sample Looding}

Place lead selenate on the filament and slurry with distilled water. Dry sample with a gentle heat.

\section{Comments}

The filament should be prebaked to help reduce any hydrocarbon background, as it frequently causes interference. $\mathrm{Se}^{+}, \mathrm{SeO}^{+}$, and $\mathrm{SeO}_{{ }_{2}}{ }^{+}$have relative intensities of 1,2 , and 3 , respectively. $\mathrm{Se}_{2}{ }^{2+}$ gives interference at $\mathrm{Se}^{+}$.

There is no interference from previous selenium samples at $\mathrm{SeO}^{+}$and $\mathrm{SeO}_{2}{ }^{+}$.

Corrections for $\mathrm{O}^{17}$ and $\mathrm{O}^{18}$ may be necessary.

Lead selenate is prepared by dissolving elemental selenium in ammonia and hydrogen peroxide and precipitating the selenium by adding lcad acetate and then acetic acid.

\begin{tabular}{ccc}
\multicolumn{3}{l}{ Mosses of } \\
\hline $\mathrm{Se}^{+}$ & $\mathrm{SeO}^{+}$ & $\mathrm{SeO}_{2}{ }^{+}$ \\
\hline 74 & 90 & 106 \\
76 & 92 & 108 \\
77 & 93 & 109 \\
78 & 94 & 110 \\
80 & 96 & 112 \\
82 & 98 & 114 \\
\hline
\end{tabular}


Silicon

\begin{tabular}{|c|c|c|c|}
\hline \multicolumn{2}{|c|}{ Preferred Conditions } & \multicolumn{2}{|c|}{$\begin{array}{c}\text { Relative Abundance } \\
\text { of Isotopes }\end{array}$} \\
\hline & & \multirow{2}{*}{$\begin{array}{c}\text { Isotope } \\
28\end{array}$} & \multirow{2}{*}{$\begin{array}{c}\text { Atom \% } \\
92.21\end{array}$} \\
\hline Compound & $\mathrm{BaSiF}_{6}$ & & \\
\hline Sample filament & Tantalum & 29 & 4.70 \\
\hline Filament size & $2 \times 60$ mils & 30 & 3.09 \\
\hline Ionization & Electron bombardment & & \\
\hline Temperature range & $<200^{\circ} \mathrm{C}$ & & \\
\hline Ion measured & $\mathrm{SiF}_{3}{ }^{+}$ & & \\
\hline
\end{tabular}

\section{Sample Looding}

Place barium fluorosilicate on the filament and slurry with distilled water. Dry sample with a gentle heat.

\section{Comments}

Optimum temperature must be approached very slowly after $\mathrm{SiF}_{3}{ }^{+}$first appears.

$\mathrm{BaSiF}_{6}$ is prepared by dissolving 1-2 mg samples of $\mathrm{SiO}_{2}$ in diluted $\mathrm{HF}$ followed by a precipitation with $\mathrm{BaCl}_{2}$. The sample is recovered by centrifuging in plastic.

\begin{tabular}{ccccc}
\multicolumn{5}{c}{ Mosses of Isotopic lons } \\
\hline $\mathrm{Si}^{+}$ & $\mathrm{SiF}^{+}$ & $\mathrm{SiF}_{2}^{+}$ & $\mathrm{SiF}_{3}{ }^{+}$ & $\mathrm{SiF}_{4}{ }^{+}$ \\
\hline 28 & 47 & 66 & 85 & 104 \\
29 & 48 & 67 & 86 & 105 \\
30 & 49 & 68 & 87 & 106 \\
\hline
\end{tabular}




\section{Silver}

\begin{tabular}{ll||cc}
\hline \multicolumn{2}{c||}{ Preferred Conditions } & \multicolumn{2}{c}{$\begin{array}{c}\text { Relative Abundance } \\
\text { of Isotopes }\end{array}$} \\
\cline { 3 - 3 } & & Isotope & Atom \% \\
\hline $\begin{array}{l}\text { Compound } \\
\text { Sample filament }\end{array}$ & $\mathrm{AgNO}_{3}$ & 107 & 51.35 \\
$\begin{array}{l}\text { Filament size } \\
\text { Ionization }\end{array}$ & $1 \times 30 \mathrm{mils}$ & 109 & 48.65 \\
Temperature range & Thermal & & \\
Ion measured & $1100-1400^{\circ} \mathrm{C}$ & & \\
\hline
\end{tabular}

\section{Sample Loading}

Place the silver nitrate solution on the filament and add a drop of saturated boric acid solution.

Dry mixture with a gentle heat; then increase filament temperature to a dull-red heat $\left(\sim 750^{\circ} \mathrm{C}\right)$.

\section{Comments}

Interference from previous silver samples has not been observed.

$\mathrm{Ag}$ metal can be converted to nitrate on filament by addition of a drop of concentrated $\mathrm{HNO}_{3}$ and heating.

AgI can be used for analysis using the following conditions:

$$
\begin{aligned}
& 2 \times 60 \mathrm{mil} \text { tantalum filament } \\
& \text { Electron bombardment } \\
& <200^{\circ} \mathrm{C} \text { filament temperature }
\end{aligned}
$$

Data taken at $\mathrm{Ag}^{+}$

Other ions observed are $\mathrm{Ag}_{2}{ }^{+}, \mathrm{Ag}_{3}{ }^{+}, \mathrm{AgI}^{+}, \mathrm{Ag}_{2} \mathrm{I}^{+}$, and $\mathrm{AgI}_{2}{ }^{+}$. 
Sodium

\begin{tabular}{ll||cc}
\hline \multicolumn{2}{c||}{ Preferred Conditions } & \multicolumn{2}{c}{$\begin{array}{c}\text { Relative Ábundance } \\
\text { of Is otopẹs }\end{array}$} \\
\cline { 3 - 3 } & & Isotope & 100 \\
Compound & $\mathrm{NaOH}$ & 23 & \\
Sample filament & Tantalum \\
Filament size & $1 \times 30 \mathrm{mils}$ \\
Ionization & Thermal \\
Temperature range & $<800^{\circ} \mathrm{C}$ \\
Ion measured & $\mathrm{Na}^{+}$ & \\
\hline
\end{tabular}

\section{Sample Looding}

Place sodium hydroxide solution on the filament and dry with a gentle heat.

\section{Comments}

Most tantalum filaments conta in residual sodium. The major part of these impurities can be removed by prebaking the filament at $6.0 \mathrm{amp}$ for $1.5 \mathrm{~min}$ at a pressure of $5 \times 10^{-5}$ torr.

The temperature at which $\mathrm{Na}^{+}$first appears is unpredictable and may vary over a wide range.

Temperature must be increased slowly because excessive heat generally produces an erratic beam.

Interference from previous sodium samples is a very serious problem. 
Strontium

\begin{tabular}{ll||cc}
\hline \multicolumn{2}{c||}{ Preferred Conditions } & \multicolumn{2}{c}{$\begin{array}{c}\text { Relative Abundance } \\
\text { of Isotopes }\end{array}$} \\
\cline { 3 - 4 } & & Isotopes & Atom $\%$ \\
\hline Compound & $\mathrm{Sr}^{2}\left(\mathrm{NO}_{3}\right)_{2}$ & 84 & 0.56 \\
Sample filament & Tantalum & 86 & 9.86 \\
Filament size & $1 \times 30 \mathrm{mils}$ & 87 & 7.02 \\
Ionization & Thermal & 88 & 82.56 \\
Temperature range & $1200-1500^{\circ} \mathrm{C}$ & & \\
Ion measured & $\mathrm{Sr}^{+}$ & & \\
\hline
\end{tabular}

\section{Somple Loading}

Place strontium nitrate solution on the filament and dry with a gentle heat.

\section{Comments}

Most tantalum filaments contain residual rubidium and sometimes strontium. The major part of the impurities can be removed by prebaking the filament at $6.0 \mathrm{amp}$ for $1.5 \mathrm{~min}$ at a pressure of $<5 \times 10^{-5}$ torr.

Interference from previous strontium samples is a problem.

If $\mathrm{Rb}^{85+}$ appears, a correction for $\mathrm{Rb}^{87^{+}}$is necessary.

Data can be obtained from 10 nanograms of $\mathrm{Sr}\left(\mathrm{NO}_{3}\right)_{2}$ or $\mathrm{SrSO}_{4} \cdot \mathrm{SrCl}_{2}$ requires a 100-nanogram sample for comparable data. 
Sulfur

\begin{tabular}{ll||cc}
\hline & \multicolumn{1}{c||}{ Preferred Conditions } & \multicolumn{2}{c}{$\begin{array}{c}\text { Relative Abundance } \\
\text { of Isotopes }\end{array}$} \\
\cline { 3 - 4 } & & Isotope & Atom \% \\
\hline Compound & $\mathrm{As}_{2} \mathrm{~S}_{3}$ & 32 & 95.0 \\
Sample filament & Tantalum & 33 & 0.760 \\
Filament size & $1 \times 30$ mils & 34 & 4.22 \\
Ionization & Electron bombardment & 36 & 0.0136. \\
Temperature range & $<500^{\circ} \mathrm{C}$ & & \\
Ion measured & $\mathrm{AsS}^{+}$ & & \\
\hline
\end{tabular}

\section{Somple Looding}

Place arsenic trisulfide on the filament and slurry with distilled water. Dry sample with a gentle heat.

\section{Comments}

Ions $\mathrm{AsS}^{+}, \mathrm{As}_{2} \mathrm{~S}^{+}, \mathrm{As}_{2} \mathrm{~S}_{2}{ }^{+}$, and $\mathrm{As}_{2} \mathrm{~S}_{3}{ }^{+}$are noted, but the best data is obtained at AsS ${ }^{+}$. 
Tantalum

\begin{tabular}{ll||rr}
\hline \multicolumn{1}{c||}{ Preferred Conditions } & \multicolumn{2}{c}{$\begin{array}{c}\text { Relative Abundance } \\
\text { of Isotopes }\end{array}$} \\
\cline { 3 - 3 } & & Isotope & Atom \% \\
\hline Compound & $\mathrm{Ta}_{2} \mathrm{O}_{5}$ & 180 & 0.0123 \\
Sample filament & Rhenium & 181 & 99.9877 \\
Filament size & $1 \times 15$ mils & & \\
Ionization & Electron bombardment & & \\
Temperature range & $>1500^{\circ} \mathrm{C}$ & \\
Ion measured & $\mathrm{TaO}_{2}{ }^{\prime}$ & \\
\hline
\end{tabular}

\section{Somple Loading}

Place finely divided tantalum oxide on the filament and partially digest with $1: 1$ hydrofluoric acid. BE VERY CAREFUL WHEN HANDLING HF. Dry sample with a gentle heat. Cover with a vacuum chamber and pump down to $<20 \mu$ pressure. Increase filament temperature until sample begins to reduce to tantalum metal and melt.

\section{Comments}

The observed ratio of $\mathrm{Ta}^{+}: \mathrm{TaO}^{+}: \mathrm{TaO}_{2}{ }^{+}$is approximately $1: 2: 8$. Interference from previous tantalum samples has not been observed.

When at low isotopic concentrations, base-line corrections for mass $212\left(\mathrm{Ta}^{180} \mathrm{O}_{2}{ }^{16}\right)^{+}$can be made by comparison with mass 214 and $\left.215\left[\left(\mathrm{Ta}^{1{ }^{81}} \mathrm{O}_{2}{ }^{17}\right)^{+} \text {and }\left(\mathrm{Ta}^{181} \mathrm{O}_{2}{ }^{18}\right)\right)^{\dagger}\right]$.

Correction for $\mathrm{O}^{17}$ may be necessary. 
Technetium

\begin{tabular}{|c|c|c|c|}
\hline \multirow{2}{*}{\multicolumn{2}{|c|}{ Preferred Conditions }} & \multicolumn{2}{|c|}{$\begin{array}{c}\text { Relative Abundance } \\
\text { of Isotopes }\end{array}$} \\
\hline & & \multirow{2}{*}{$\begin{array}{c}\text { Isotope } \\
99\end{array}$} & \multirow{2}{*}{ Atom $\%$} \\
\hline Compound & $\mathrm{NH}_{4} \mathrm{TcO}_{4}$ & & \\
\hline Sample filament & Iridium & & \\
\hline Filament size & $1 \times 30 \mathrm{mils}$ & & \\
\hline Ionization & Electron bombardment & & \\
\hline \multicolumn{4}{|l|}{ Temperature range } \\
\hline Ion measured & $\mathrm{Tc}^{+}$ & & \\
\hline
\end{tabular}

\section{Somple Loading}

Evaporate a solution of ammonium pertechnetate on the filament and reduce to metal by heating in $\mathrm{H}_{2}$, or electroplate technetium on the filament and heat in $\mathrm{H}_{2}$ to form a tightly adhering layer of technetium.

\section{Comments}

Technetium will produce $\mathrm{Tc}^{+}$thermally from iridium filaments.

See ORNL-1327, Mass Spectrometer Study of Technetium, by J. R. Sites, C. R. Baldock, and

L. O. Gilpatrick (August 26, 1952́). 
Tellurium

\begin{tabular}{|c|c|c|c|}
\hline \multicolumn{2}{|c|}{ Preferred Conditions } & \multicolumn{2}{|c|}{$\begin{array}{l}\text { Relative Abundance } \\
\text { of Isotopes }\end{array}$} \\
\hline & & Isotope & Atom $\%$ \\
\hline Compound & $\mathrm{Ag}_{6} \mathrm{TeO}_{6}$ & 120 & 0.089 \\
\hline Sample filament & Tantalum & 122 & 2.46 \\
\hline Filament size & $2 \times 60$ mils & 123 & 0.87 \\
\hline Ionization & Electron bombardment & 124 & 4.61 \\
\hline Temperature range & $<200^{\circ} \mathrm{C}$ & 125 & 6.99 \\
\hline \multirow[t]{3}{*}{ lon measured } & $\mathrm{IeU}_{2}{ }^{+}$ & 128 & 18.71 \\
\hline & & 128 & 31.79 \\
\hline & & 130 & 34.48 \\
\hline
\end{tabular}

\section{Sample Loading}

Place silver tellurate on the filament and slurry with distilled water. Dry sample with a gentle heat.

\section{Comments}

$\mathrm{Te}^{+}, \mathrm{TeO}^{+}$, and $\mathrm{TeO}_{2}^{+}$appear. The highest ratio of ion current to hydrocarbon background is at $\mathrm{TeO}_{2}^{+}$.

$\mathrm{Ag}^{+}, \mathrm{AgO}^{+}, \mathrm{AgO}_{2}{ }^{+}$and $\mathrm{Ag}_{2}{ }^{+}$are observed but do not interfere.

Interference from previous tellurium samples is a serious problem.

Corrections for $\mathrm{O}^{17}$ and $\mathrm{O}^{18}$ may be necessary.

$\mathrm{Ag}_{6} \mathrm{TeO}_{6}$ is prepared by dissolving elemental tellurium in ammonia and hydrogen peroxide, and precipitating tellurium with silver ions from a neutral solution. 


\begin{tabular}{ll||cc}
\hline \multicolumn{1}{c||}{ Preferred Conditions } & \multicolumn{2}{c}{$\begin{array}{c}\text { Relative Abundance } \\
\text { of Isotopes }\end{array}$} \\
\cline { 3 - 3 } Compound & $\mathrm{Tb}_{2} \mathrm{O}_{3}$ & 159 & Atom $\%$ \\
Sample filament & Tantalum & & \\
Filament size & $1 \times 30 \mathrm{mils}$ \\
Ionization & Thermal & \\
Temperature range & $1400-1700^{\circ} \mathrm{C}$ & \\
Ion measured & $\mathrm{TbO}^{+}$ & \\
\hline
\end{tabular}

\section{Sample Loading}

Place finely divided terbium oxide on the filament and partially digest with concentrated nitric acid. Dry sample with a gentle heat; then increase filament temperature to a dull-red heat. $\left(\sim 750^{\circ} \mathrm{C}\right)$.

\section{Comments}

One microgram of terbium produces an ion current of $10^{-10}$ amp for more than an hour.

The observed ratio of $\mathrm{Tb}^{+}$to $\mathrm{TbO}^{+}$is $1:>100$.

Interference from previous terbium samples has not been observed. 
Thallium

\begin{tabular}{|c|c|c|c|}
\hline \multirow{2}{*}{\multicolumn{2}{|c|}{ Preferred Conditions }} & \multicolumn{2}{|c|}{$\begin{array}{c}\text { Relative Abundance } \\
\text { of Isotopes }\end{array}$} \\
\hline & & \multirow{2}{*}{$\begin{array}{c}\text { Isotope } \\
203\end{array}$} & \multirow{2}{*}{$\begin{array}{r}\text { Atom \% } \\
29.50\end{array}$} \\
\hline Compound & $\mathrm{Tl}\left(\mathrm{NO}_{3}\right)_{3}$ & & \\
\hline Sample filament & Tungsten & 205 & 70.50 \\
\hline Filament size & $1 \times 30 \mathrm{mils}$ & & \\
\hline Ionization & Thermal & & \\
\hline Temperature range & $1000-1400^{\circ} \mathrm{C}$ & & \\
\hline Ion measured & $\mathrm{T}^{+}$ & & \\
\hline
\end{tabular}

\section{Sample Loading}

Place the thallium nitrate solution on the filament and add a drop of saturated boric acid solution Dry this mixture with a gentle heat; then increase filament temperature to a dull-red heat $\left(\sim 750^{\circ} \mathrm{C}\right)$.

\section{Comments}

The $\mathrm{Tl}^{+}$beam will decrease soon after it first appears. Additional increase of temperature will produce a stable and higher ion current.

Any $\mathrm{Pb}$ contamination will appear as the $\mathrm{T} 1$ ions die away.

Interference from previous thallium samples has not been observed.

$\mathrm{Tl}_{2} \mathrm{O}_{3}$ is converted to nitrate on the filament by addition of nitric acid. Proceed as described for nitrate. 
Thorium

\begin{tabular}{ll||cc}
\hline \multicolumn{1}{c||}{ Preferred Conditions } & \multicolumn{2}{c}{$\begin{array}{c}\text { Relative Abundance } \\
\text { of Isotopes }\end{array}$} \\
\cline { 3 - 3 } & & $\mathrm{ThO}_{2}$ & Atom \% \\
\hline Compound & Tantalum & 232 & 100 \\
Sample filament & $1 \times 30 \mathrm{mils}$ \\
Filament size & Thermal & & \\
Ionization & $>1700^{\circ} \mathrm{C}$ & \\
Temperature range & $\mathrm{ThO}^{+}$ & \\
Ion measured & & \\
\hline
\end{tabular}

\section{Sample Looding}

Place finely divided thorium oxide on the filament and partially digest the sample with a drop of concentrated nitric acid. Dry sample with a gentle heat; then increase filament temperature to a dull-red heat $\left(\sim 750^{\circ} \mathrm{C}\right)$.

\section{Comments}

Interference from previous thorium samples has not been observed. 
Thulium

\begin{tabular}{|c|c|c|c|}
\hline \multicolumn{2}{|c|}{ Preferred Conditions } & \multicolumn{2}{|c|}{$\begin{array}{l}\text { Relative Abundance } \\
\text { of Isotopes }\end{array}$} \\
\hline & & \multirow{2}{*}{$\begin{array}{c}\text { Is otope } \\
169\end{array}$} & \multirow{2}{*}{$\begin{array}{c}\text { Atom \% } \\
100\end{array}$} \\
\hline Compound & $\mathrm{Tm}_{2} \mathrm{O}_{3}$ & & \\
\hline Sample filament & Tantalum & & \\
\hline Filament size & $1 \times 30 \mathrm{mils}$ & & \\
\hline Ionization & Thermal & & \\
\hline Temperature range & $1400-1700^{\circ} \mathrm{C}$ & & \\
\hline Iơii meàsüurèd & $\mathrm{Im}{ }^{\star}$ & & \\
\hline
\end{tabular}

\section{Sample Looding}

Place finely divided thulium oxide on the filament and partially digest with concentrated nitric acid. Dry sample with a gentle heat; then increase filament temperature to a dull-red heat $\left(\sim 750^{\circ} \mathrm{C}\right)$.

\section{Comments}

One microgram of thulium produces an ion current of $10^{-10}$ amp for an hour. The observed ratio of $\mathrm{Tm}^{+}$to $\mathrm{TmO}^{+}$is $>100: 1$.

Interference from previous thulium samples has not been observed. 
Tin

\begin{tabular}{ll||rr}
\hline \multicolumn{1}{c||}{} & \multicolumn{1}{c||}{ Preferred Conditions } & \multicolumn{2}{c}{$\begin{array}{c}\text { Relative Abundance } \\
\text { of Is otopes }\end{array}$} \\
\cline { 3 - 4 } & & Isotope & Atom \% \\
\hline Compound & $\mathrm{Sn}$ & 112 & 0.96 \\
Sample filament & Tungsten & 114 & 0.66 \\
Filament size & $1 \times 30$ mils & 115 & 0.35 \\
Ionization & Electron bombardment & 116 & 14.30 \\
Temperature range & $800-1200^{\circ} \mathrm{C}$ & 117 & 7.61 \\
Ion measured & $\mathrm{Sn}^{+}$ & 118 & 24.03 \\
& & 119 & 8.58 \\
& & 120 & 32.85 \\
& & 122 & 4.72 \\
& & 124 & 5.94 \\
\hline
\end{tabular}

\section{Somple Loading}

Place finely divided tin metal on the filament. Cover with a vacuum chamber and pump down to $<20 \mu$ pressure. Increase filament temperature until sample melts.

\section{Comments}

The $\mathrm{Sn}^{+}$. intensity will decrease soon after it first appears. Additional increase of temperature will produce a stable and higher ion current.

Memory from previous tin samples has not been observed.

The ratio of $\mathrm{Sn}^{+}$to $\mathrm{SnO}^{+}$varies widely. 
Titanium

\begin{tabular}{ll||cr}
\hline \multicolumn{1}{c||}{ Preferred Conditions } & \multicolumn{2}{c}{$\begin{array}{c}\text { Relative Abundance } \\
\text { of Isotopes }\end{array}$} \\
\cline { 3 - 4 } & & Isotope & Atom \% \\
\hline Compound & $\mathrm{TiO}_{2}$ & 46 & 7.93 \\
Sample filament & $\mathrm{Tantalum}^{1}$ & 47 & 7.28 \\
Filament size & $1 \times 30 \mathrm{mils}$ & 48 & 73.94 \\
Ionization & Thermal & 49 & 5.51 \\
Temperature range & $1300-1600^{\circ} \mathrm{C}$ & 50 & 5.34 \\
Ion measured & $\mathrm{liO}^{*}$ & & \\
\hline
\end{tabular}

\section{Somple Loading}

Place finely divided titanium oxide on the filament and slurry with distilled water. Dry sample with a gentle heat.

\section{Comments}

The ratio of $\mathrm{Ti}^{+}$to $\mathrm{TiO}^{+}$is a pproximately $1: 5$.

Interference from previous titanium samples has not been observed.

Corrections for $\mathrm{O}^{17}$ and $\mathrm{O}^{18}$ may be necessary. 
Tungsten

\begin{tabular}{ll||cc}
\hline \multicolumn{1}{c||}{ Preferred Conditions } & \multicolumn{2}{c}{$\begin{array}{c}\text { Relative Abundance } \\
\text { of Isotopes }\end{array}$} \\
\cline { 3 - 3 } & & Isotope & Atom $\%$ \\
\hline Compound & $\mathrm{WO}_{3}$ & 180 & 0.135 \\
Sample filament & Tantalum & 182 & 26.41 \\
Filament size & $1 \times 30 \mathrm{mils}$ & 183 & 14.40 \\
Ionization & Electron bombardment & 184 & 30.64 \\
Temperature range & $900-1200^{\circ} \mathrm{C}$ & 186 & 28.41 \\
Ion measured & $\mathrm{WO}_{2}{ }^{+}$ & & \\
\hline
\end{tabular}

\section{Sample Loading}

Place finely divided tungsten oxide on the filament and slurry with a saturated boric acid solution. Dry sample with a gentle heat; then increase filament temperature to a dull-red heat $\left(\sim 750^{\circ} \mathrm{C}\right)$.

\section{Comments}

The $\mathrm{WO}_{2}{ }^{+}$beam will decrease soon after it first appears. Additional increase of temperature will produce a stable and higher ion intensity. The $\mathrm{H}_{3} \mathrm{BO}_{3}$ tends to stabilize the ion beam.

Interference from previous tungsten samples has not been observed.

Corrections for $\mathrm{O}^{17}$ and $\mathrm{O}^{18}$ may be necessary.

G. H. Palmer* reports that the thermal ion, $\mathrm{Na}_{2} \mathrm{WO}_{4}{ }^{+}$, has been obtained from sodium tungstate on a tantalum filament.

\begin{tabular}{ccc}
\hline \multicolumn{3}{c}{ Masses of Isotopic lons } \\
\hline $\mathrm{W}^{+}$ & $\mathrm{WO}^{+}$ & $\mathrm{WO}_{2}{ }^{+}$ \\
\hline 180 & 196 & 212 \\
182 & 198 & 214 \\
183 & 199 & 215 \\
184 & 200 & 216 \\
186 & 202 & 218 \\
\hline
\end{tabular}

*G. H. Palmer, in Advances in Mass Spectrometry, ed. by J. D. Waldron, Pergamon Press, New. Yurk, 1959. 


\begin{tabular}{|c|c|c|c|}
\hline \multicolumn{4}{|c|}{ Vanadium } \\
\hline \multicolumn{2}{|c|}{ Preferred Conditions } & \multicolumn{2}{|c|}{$\begin{array}{c}\text { Relative Abundance } \\
\text { of Isotopes }\end{array}$} \\
\hline & & \multirow{2}{*}{$\frac{\text { Isotope }}{50}$} & \multirow{2}{*}{$\frac{\text { Atom } \%}{0.24}$} \\
\hline Compound & $\mathrm{V}_{2} \mathrm{O}_{5}$ & & \\
\hline Sample filament & Tantalum & 51 & 99.76 \\
\hline Filament size & $1 \times 30 \mathrm{mils}$ & & \\
\hline Ionization & Thermal & & \\
\hline Temperature range & $1400-1600^{\circ} \mathrm{C}$ & & \\
\hline Ion measured & $\mathrm{V}^{+}$ & & \\
\hline
\end{tabular}

\section{Sample Loading}

Place vanadium oxide on the filament and slurry with distilled water. Dry sample with a gentle heat.

\section{Comments}

Interference from previous vanadium samples has not been observed.

The ratio of $\mathrm{V}^{+}$to $\mathrm{VO}^{+}$is approximately $10: 1$. 


\section{Uranium}

\begin{tabular}{ll||cc}
\hline \multicolumn{2}{c||}{ Preferred Conditions } & \multicolumn{2}{c}{$\begin{array}{c}\text { Relative Abundance } \\
\text { of Isotopes }\end{array}$} \\
\cline { 3 - 4 } & & Isotope & Atom \% \\
\hline Compound & $\mathrm{U}_{3} \mathrm{O}_{8}$ & 234 & 0.0056 \\
Sample filament & Tantalum & 235 & 0.7205 \\
Filament size & $1 \times 30 \mathrm{mils}$ & 238 & 99.2739 \\
Ionization & Thermal & & \\
Temperature range & $1500-1700^{\circ} \mathrm{C}$ & & \\
Ion measured & $\mathrm{UO}_{2}{ }^{+}$ & & \\
\hline
\end{tabular}

\section{Sample Loading}

P.lace finely divided uranium oxide on the filament and partially digest the sample with a drop of concentrated nitric acid. Dry sample with a gentle heat; then increase filament temperature to a dull-red heat $\left(\sim 750^{\circ} \mathrm{C}\right)$.

\section{Comments}

Approximately $50 \mu \mathrm{g}$ of uranium is normally used for analysis.

Data have been obtained from $<10-\mu \mathrm{g}$ samples.

When $\mathrm{UO}_{2}{ }^{+}$first appears, the intensity sometimes increases slowly for a few minutes and then rapidly. If this occurs the filament temperature must be reduced to avoid losing the sample.

Interference from previous uranium samples has not been observed.

Corrections for $\mathrm{O}^{17}$ and $\mathrm{O}^{18}$ may be necessary.

Small samples ( $<1$ to 10 nanograms) are analyzed using an electron multiplier receiver. The sample is loaded as uranium nitrate on a tungsten filament. When the pressure in the source area is approximately $1 \times 10^{-7}$ torr, benzene vapor is introduced to increase the pressure to $5 \times 10^{-5}$. The sample and filament are then conditioned by increasing the filament temperature to $1600^{\circ} \mathrm{C}$ for $30 \mathrm{sec}$. $\mathrm{U}^{+}$is the ion measured, and the temperature range is 1750 to $1850^{\circ} \mathrm{C}$. 
Ytterbium

\begin{tabular}{ll||cc}
\hline \multicolumn{1}{c||}{ Preferred Conditions } & \multicolumn{2}{c}{$\begin{array}{c}\text { Relative Abundance } \\
\text { of Isotopes }\end{array}$} \\
\cline { 3 - 4 } & & Isotope & Atom \% \\
\hline Compound & $\mathrm{Yb}_{2} \mathrm{O}_{3}$ & 168 & 0.135 \\
Sample filament & $\mathrm{Tantalum}$ & 170 & 3.03 \\
Filament size & $1 \times 30 \mathrm{mils}$ & 171 & 14.31 \\
Ionization & Thermal & 172 & 21.82 \\
Temperature range & $1300-1700^{\circ} \mathrm{C}$ & 173 & 16.13 \\
Ion measured & $\mathrm{Yb}^{+}$ & 174 & 31.84 \\
& & 176 & 12.73 \\
\hline
\end{tabular}

\section{Sample Loading}

Place finely divided ytterbium oxide on the filament and partially digest with concentrated nitric acid. Dry sample with a gentle heat; then increase filament temperature to a dull-red heat $\left(\sim 750^{\circ} \mathrm{C}\right)$.

\section{Comments}

One microgram of ytterbium produces an ion current of $10^{-10}$ amp for more than an hour. The observed ratio of $\mathrm{Yb}^{+}$to $\mathrm{YbO}^{+}$is $>100: 1$.

Interference from previous ytterbium samples has not been observed. 
Zinc

\begin{tabular}{ll||cc}
\hline \multicolumn{1}{c||}{} & \multicolumn{2}{c}{$\begin{array}{c}\text { Relative Abundance } \\
\text { of Isotopes }\end{array}$} \\
\cline { 3 - 4 } & & Isotope & Atom \% \\
\hline Compound & $\mathrm{ZnO}$ & 64 & 48.89 \\
Sample filament & Tantalum & 66 & 27.81 \\
Filament size & $2 \times 60 \mathrm{mils}$ & 67 & 4.11 \\
Ionization & Electron bombardment & 68 & 18.57 \\
Temperature range & $800-1200^{\circ} \mathrm{C}$ & 7.0 & 0.62 \\
Ion measured & $\mathrm{Zn}^{+}$ & & \\
\hline
\end{tabular}

\section{Sample Looding}

Place zinc oxide on the filament and slurry with distilled water. Dry sample with a gentle heat.

\section{Comments}

The $\mathrm{Zn}^{+}$beam will decrease soon after it first appears. Additional increase of temperature will produce a stable and higher ion current. Hydrocarbon background frequently causes interference. Interference from previous $z$ inc samples is a very serious problem.

$\mathrm{ZnI}_{2}$ and $\mathrm{ZnF}_{2}$ are compounds that have been used for analysis. 
Zirconium

\begin{tabular}{ll||cc}
\hline \multicolumn{1}{c||}{ Preferred Conditions } & \multicolumn{2}{c}{$\begin{array}{c}\text { Relative Abundance } \\
\text { of Isotopes }\end{array}$} \\
\cline { 3 - 4 } & $\mathrm{ZrO}_{2}$ & 90 & Atom $\%$ \\
\hline Compound & Tantalum & 91 & 51.46 \\
Sample filament & $1 \times 30 \mathrm{mils}$ & 92 & 11.23 \\
Filament size & Thermal & 94 & 17.11 \\
Ionization & $1600-1900^{\circ} \mathrm{C}$ & 96 & 17.40 \\
Temperature range & $\mathrm{ZrO}^{+}$ & & 2.80 \\
Ion measured & & & \\
\hline
\end{tabular}

\section{Somple Looding}

Place finely divided zirconium oxide on the filament and slurry with distilled water. Dry sample with a gentle heat.

\section{Comments}

The $\mathrm{ZrO}^{+}$beam will decrease soon after it first appears. Additional increase of temperature will produce a stable and higher ion current.

The observed ratio of $\mathrm{Zr}_{\mathrm{r}}^{+}$to $\mathrm{ZrO}^{+}$is approximately $1: 10$.

Interference from previous $z$ irconium samples has not been observed.

Corrections for $\mathrm{O}^{17}$ and $\mathrm{O}^{18}$ may be necessary. 


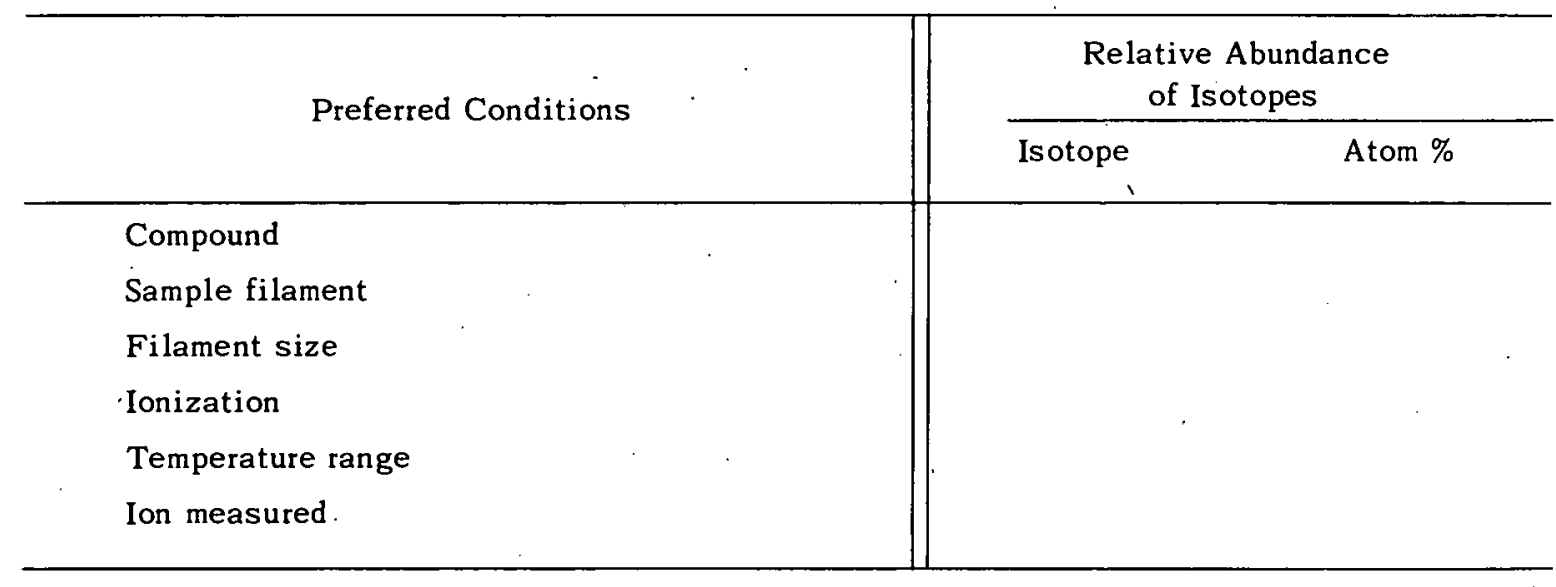

\section{Somple Loading}

\section{Comments}




\begin{tabular}{l||l}
\hline \multicolumn{1}{c||}{ Preferred Conditions } & \multicolumn{2}{c}{$\begin{array}{c}\text { Relative Abundance } \\
\text { of Isotopes }\end{array}$} \\
\hline $\begin{array}{l}\text { Compound } \\
\text { Sample filament } \\
\text { Filament size } \\
\text { Ionization } \\
\text { Temperature range }\end{array}$ & \\
Ion meisured & \\
\hline
\end{tabular}

Sample Loading

\section{Comments}




\begin{tabular}{l||l}
\hline \multicolumn{1}{|c||}{ Preferred Conditions } & \multicolumn{2}{c}{$\begin{array}{c}\text { Relative Abundance } \\
\text { of Isotopes }\end{array}$} \\
\hline $\begin{array}{l}\text { Compound } \\
\text { Sample filament }\end{array}$ & \\
$\begin{array}{l}\text { Filament size } \\
\text { Ionization } \\
\text { Temperature range } \\
\text { Ion measured }\end{array}$ & \\
\hline
\end{tabular}

Somple Loading

Comments 


\begin{tabular}{|c|c|c|}
\hline \multirow{2}{*}{ Preferred Conditions } & \multicolumn{2}{|c|}{$\begin{array}{l}\text { Relative Abundance } \\
\text { of Isotopes }\end{array}$} \\
\hline & Isotope & Atom \% \\
\hline \multicolumn{3}{|l|}{ Compound } \\
\hline \multicolumn{3}{|l|}{ Sample filament } \\
\hline \multicolumn{3}{|l|}{ Filament size } \\
\hline \multicolumn{3}{|l|}{ Ionization } \\
\hline \multicolumn{3}{|l|}{ Temperature range } \\
\hline Ion measured & & \\
\hline
\end{tabular}

\section{Somple Looding}

\section{Comments}




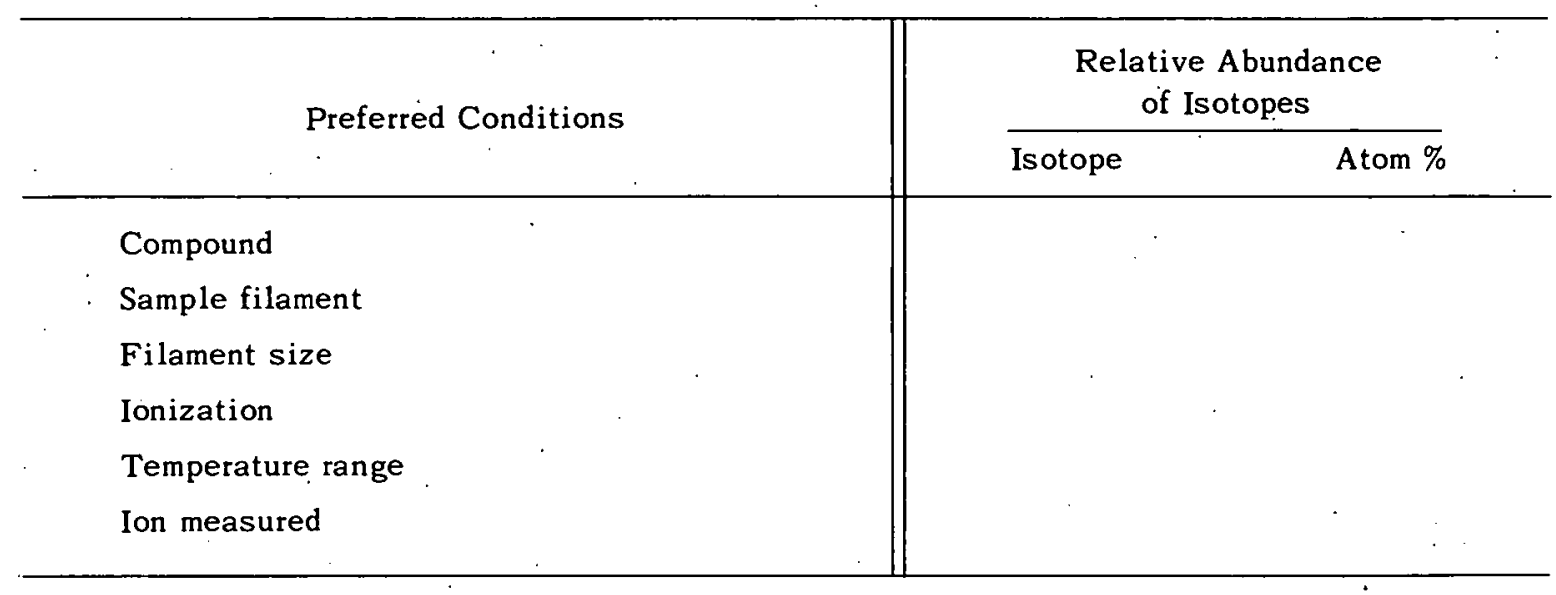

\section{Sample Loading}

\section{Comments}




\begin{tabular}{l||l}
\multicolumn{1}{c||}{ Preferred Conditions } & \multicolumn{1}{c}{$\begin{array}{c}\text { Relative Abundance } \\
\text { of Isotopes }\end{array}$} \\
\cline { 2 - 2 } $\begin{array}{l}\text { Compound } \\
\text { Sample filament } \\
\text { Filament size } \\
\text { Ionization } \\
\text { Temperature range } \\
\text { Ion measured }\end{array}$ & \\
\hline
\end{tabular}

Sample Looding

Comments 
ORNL-3528

UC. 4 - Chemistry

TID.4500 (24th ed.)

\section{INTERNAL DISTRIBUTION}

1. C. E. Lorson

2. A. M. Weinberg

3. J. A. Swartout

4. G. E. Boyd

5. M. T. Kelley

6. L. T. Corbin

7. J. C. White

8. E. J. Spitzer

9. J. R. Sites
10. A. E. Cameron

11. M. J. Skinner

12. Biology Library

13-15. Central Research Library

16. Reactor Division Library

17-18. ORNL - Y-12 Technical Library

Document Reference Section

19-229. Laboratory Records Department

230. Laboratory Records, ORNL R.C.

\section{EXTERNAL DISTRIBUTION}

231. Research and Development

Division, AEC, ORO

232-822. Given distribution as shown in TID-4500 (24th ed.) under Chemistry Category (75 copies - OTS) 